\title{
PLANT HORMONE-MEDIATED REGULATION OF STRESS RESPONSES IN FRUIT CROPS- A REVIEW
}

\author{
Vinaykumar Rachappanavar ${ }^{1}$, Manish Kumar ${ }^{2}$, JK Sharma ${ }^{3}$, Himanshu Panday ${ }^{2}$, and CL \\ sharma ${ }^{2}$ \\ ${ }^{1}$ Affiliation not available \\ ${ }^{2}$ Dr Yashwant Singh Parmar University of Horticulture and Forestry \\ ${ }^{3}$ Baddi University of Emerging Sciences and Technology School of Pharmacy and Emerging \\ Sciences
}

November 6, 2020

\begin{abstract}
One of the challenges facing fruit crop production globally is the regional climate regimes are becoming more unpredictable year after year leading to various type of stress. The exact impact of these stress on fruit crops is difficult to predict. Plant hormones can improve tolerance against abiotic stresses by inhibiting or reducing the active oxygen (AOS) accumulation, electrolyte leakage, induce the expression of stress-specific genes, etc. Among the major hormones produced by the plants, ABA, SA, JA and ET are known to play major roles in mediating plant defence response against various abiotic stresses. Crosstalk networks among phytohormones mediated by diverse key regulators have been extensively investigated and documented in various research investigations. Many canvassers' recommended the use of phytohormones to counteract abiotic stress as increasing stress tolerance through conventional breeding methods requires longer time and also leads to inadequate adoptability of such cultivars under diverse cultivation environment for validation of performance and heritability. In this review, we summarize the roles of the major phytohormones present in fruit crops in regulating abiotic stresses responses with special focus on the significance of crosstalk between various hormones at biochemical and molecular level in generating a sophisticated and efficient stress response.
\end{abstract}

\section{INTRODUCTION}

Fruit crops are highly vulnerable to different environmental stresses. These stresses are grouped into two main categories- biotic and abiotic- based on the nature of stimulants. Biotic stresses are caused by various fungi, bacteria, viruses, nematodes, insects, and weeds. Whereas the second group is linked with the physiographic, climatic, and edaphic components of the environment affecting plant development and productivity (Verma A, 2016). The concern about these stresses in horticultural crops is important due to reducing annual production year after year by climate change (Bray et al., 2000). These stresses may cause morphological, physiological, biochemical, and molecular changes in plants (Dos Reis et al., 2012). Morphological changes like retarded shoot and root growth, flower drop, low fruit setting, deformed fruit shape are observed during abiotic stress conditions. Nutrient content and their proportion may change with the intensity of stress. To survive under unfavorable environmental condition plants need to regulate their growth and development (Wolters and Jurgens, 2009). They produce excessive reactive oxygen species leading to an oxidative stress condition in plants (Noctor et al., 2015). As a consequence of facing stressful situations, plants produce defensive biochemicals leading to neutralize the negative impact of abiotic stress (Herbette et al., 2007).

The exact impact of these stress on fruit crops is difficult to predict and it depends on numerous other climatic factors that are all always counted in predictive models. Most of the time, several abiotic stresses 
occur and simultaneously affect plant growth and development. In this situation, studying individual stress separately without considering other stress factors is not adequate because plant response is unique and can be predicted but the similar results may appear by each stress factor applied individually (Mittler R, 2006). Plants do have root system architecture (RSA) to respond to changing environment and it facilitates lateral root branching which enables plants to withstand stress conditions (Lavenus et al., 2013). Moreover, abiotic and biotic components typically interact in a given ecosystem (Pandey P et al., 2017). Focusing on horticulture crops concerning abiotic stress is important because they are considered as cash crops and provide essential dietary elements (Shannon MC and Grieve CM, 1998).

According to the Global Burden of Disease study, nearly 3.4 million deaths can be attributed due to shortage of fruit and vegetable production and consumption yearly (http://www.fao.org/3/a-i6807e.pdf). Therefore, need to grow a vast amount of horticultural crops under diverse stress conditions becomes the most important goal for the current agriculture scenario to provide a properly balanced diet to every person. Since 2000, extensive studies were conducted to know the exact impact of climate change encompassing all abiotic stresses but only few research articles pay attention to fruit crops in terms of quality fruit production under abiotic stress conditions (Parajuli R et al., 2019). In that suggestion, increasing phytohormones biosynthesis and external application is the main concern to increase the tolerance against abiotic stress in fruit crops with a less economic burden. To maintain the normal plant physiological activities in plants, it is essential to understand clearly how these stress factors respond to different hormones at different stages of plant growth (Wien, 1997).

Traditional agronomical approaches do not have the potential to completely overcome the impact of environmental stresses. Therefore, it is important to use a modern molecular approach like marker-assisted selection (MAS), association mapping, QTL mapping, and whole-genome sequencing used to enhance the knowledge of tolerance in new cultivars. Limited work was accomplished at the DNA level to know stress tolerance in fruit crops (Gong et al., 2010). Several studies have shown that the stress tolerance influencing genes are present in the different fruit crops (Song et al., 2012). Generally stacking traits breeding method is used to introduce the numerous valuable genes for crop improvement but this method is inadequate because of the attribute segregation which disturbs the selection (Ainley et al., 2013). However, zinc finger nucleases are more useful for producing trait landing pads (Belhaj et al., 2013). There are three common methods of QTL model which are used in fruit crop improvement. Those are Single marker-assisted, simple interval mappings, and composite interval mappings, in which single marker-assisted QTL mapping are widely used (Collard et al., 2005). Till, now only few QTLs and genes have been identified in fruit crops which are involved in stress level regulating activities. The introduction and improvement of stress tolerance through a conventional breeding method does not provide the required result because of the linkage drag of unknown characters from donor parents (Asins, 2002). So the study of phytohormones becomes essential because they have some amount of stress regulation mechanism directly or indirectly without any negative effect on plants. Hence, it is necessary to understand the functional significance of major phytohormones in plants exposed to harsh environmental conditions. The current review presents an overview of the frontiers of phytohormones research in plant abiotic stress responses.

\section{Phytohormones}

Plant hormones are bimolecular compounds required in small quantities (Fahed et al., 2015) to regulate normal physiological activities. These organic molecules manage the abiotic stress by forming complex signaling cascades from stimuli perception to abiotic specific gene expression (Azevedo et al., 2012). They play key roles in plants by modifying growth and development (Wani et al., 2016). They include gibberellic acid (GA), auxin (AUX), cytokinin (CK), abscisic acid (ABA), ethylene (ET), salicylic acid (SA) and jasmonates (JAs) which are involved in different stress regulation activities directly or indirectly. They act as a chemical messenger with highly complex regulation mechanism, these biomolecules allow plants to maintain normal growth plasticity even under stress conditions (Xu et al., 2016). Various studied have shown that different plant hormones can improve plant tolerance against various abiotic stress conditions (Ogawa et al., 2005) by inhibiting or reducing the active oxygen species (AOS) accumulation, electrolyte leakage, induce the expres- 
sion of stress-specific genes and enhance the photosynthesis (Kang et al., 2004), as the AOS level increase in the cell can damage nucleic acid molecules, protein, lipids, and other biomolecules (Noctor and Foyer., 1998). Furthermore, DELLA proteins work collaterally with GAs, which leads to an increase in tolerance against environmental stresses (Achard et al., 2009). However, the identification of novel genes and its stress responses may prove to be a vibrant target for engineering abiotic stress tolerance in fruit crops. More information is needed to have celerity regarding the regulation of abiotic stress at hormonal levels in fruit crops along with how and which hormones regulate different abiotic stresses.

\subsection{Role of Auxin in plant defense response}

Auxin is an essential biomolecule that regulates cell elongation, cell division, apical dominance, differentiation, apical dominance, tropical response, and other biological activities in plants. Genes involved in various auxin-related pathways show variation in expression during stress conditions (Van et al., 2013). Auxin stimulates the initiation of lateral roots from primary roots at seedling stage in plants by promoting lateral root primordia (LRP) initiation through activation of root pericycle cells present opposite to xylem (Lavenus et al., 2013) with the help of multiple IAA and ARFs (Okushima et al., 2007). The members of Aux/IAA and ARF class showed variation in expression during cold stress conditions in Arabidopsis (Hannanh et al., 2005). Cheong et al. (2002) showed fluctuation in auxin-related genes expression, including IAA2, IAA3, GH3-like protein, and SAUR-AC1, after damage caused by the environment (Kovtun et al., 1998). During oxidative stress conditions, expression of PIN1, and PIN3 downregulated (Pasternak et al., 2005). Genomewide study shows that the glutaredoxin $(G R X)$ gene family exhibits differential expression patterns under different phytohormones treatment. Among them, OsGRX8, a member of GRX, has expression during different abiotic stress conditions (Garg et al., 2010). WES1, encoding auxin conjugating enzyme, is induced by drought, heat, cold, and oxidative stress conditions (Park et al., 2007). Under ABA, drought, and salt treatments, numerous auxin transport genes have shown differential regulation (Shen et al., 2010).

\subsection{Role of GA in plant defense response}

GAs are primarily growth-regulating phytohormone involved in various developmental processes, including germination, leaf expansion (Claeys et al., 2012), stem elongation (Iwamoto et al., 2011), flowering (Hyun et al., 2016) and trichome and reproductive organs development (Claeys et al., 2012). Recently researcher identified the role of GA under stress condition (Wang et al., 2017). GA signaling and metabolism is a vital critical factor for environmental stress-tolerant in resilient phenotypes. It modifies the physiological metabolism in plants with regulating sink and source relationships (Iqbal et al., 2011). The methylerythritol phosphate pathway synthesizes the gibberellic acids in plastids from trans-geranylgeranyl diphosphate, thus both GA and ABA share common precursors during biosynthesis (Banerjee et al., 2016). The pleiotropic action of GAs is modified by the degradation of DELLA proteins which belongs to the GRAS protein family (Colebrook et al., 2014). DELLAs may regulate the gene expression by acting as transcriptional activators in multiplexes with other transcription factors (TFs) (Hirano et al., 2012). In the same way, they also act as inhibitors by sequestering gene activating TFs (Feng et al., 2008). DELLAs have been observed to interact with the other phytohormone cascades at the molecular level (Bai et al., 2012) during stress conditions (Bai et al., 2008). In recent years, several tissue-specific GA dioxygenases have been identified as CsGA2ox1 ,CsGA20x2 , CsGA20ox2, CsGA3ox2 , CsGA3ox3, andCsGA20x4 in Camellia sinensis, these genes are utilized as a candidate marker gene for abiotic stress tolerance breeding (Pan et al., 2017). DREB2 , an AP2/ERF family protein was found to be induced by ABA, but suppressed by overexpression of the DREB2 gene which may cause dwarfness in rice with GA deficient symptoms and normal growth was restored by exogenous application of GA. Expression ofOsGA20ox1, OsGA20ox2, OsGA3ox2 , and OsGA20ox4 was significantly declined in the plants under stress condition especially to salt stress (Tang et al., 2017).

\subsection{Role of abscisic acid in plant defense response}

Abscisic acid (ABA) is a small organic molecule and classified as sesquiterpene (Roychoudhury et al., 2013). It plays an important role in mediating stress responses (Yang et al., 2011). When environmental conditions are unfavorable for plants growth, the ABA biosynthesis (Kim et al., 2010) and accumulation in various 
plant tissues increases drastically and bind to its receptors to initiate signal transduction that leads to stress response at the cellular level (Ng et al., 2014). Diverse ZEP genes regulate the ABA biosynthesis in different species and plant growth stages but NCED genes have a major role in drought stress conditions in tomato (Burbidge et al., 1990), bean (Qin and Zeevaart, 1999) and avocado (Chernys and Zeevaart, 2000). A remarkable rise in the NCED transcript level observed under induced dehydration conditions (Xiong and Zhu, 2003). But theNCED expression not varied by exogenous ABA application. Exogenous ABA regulates the ZEP , AAO3, and MCSUgenes. Both ABA degradation and biosynthesis have a significant role in $\mathrm{ABA}$ expression and adjusting plant stress responses and developmental strategies. ABRE and DRE like cis-elements are promoters of stress-inducible ABA genes (Xiong et al., 2001; Bray, 2002).

\subsection{Role of ethylene in plant defense response}

Ethylene has the same activities as ABA for senescence but it has a different site of action and regulates diverse biotic and abiotic stresses (Brodersen et al., 2005). Abiotic stress promotes the ethylene production by modulating the activities of ACC synthase and ACC oxidase. Underwater deficit condition, increase in ethylene level observed in avocado and orange (Upreti et al., 1999). One of the subfamilies of AP2/ERF transcription factors, Ethylene Responsive Factor VII group (ERF-VII) participates in growth and development processes and stress response mechanisms in plants (Yao et al., 2016). These proteins contain a conserved APETALA2 (AP2) domain necessary for protein-DNA interaction (Papdi et al., 2015). At the N-terminal, ERF-VII has highly conserved motif MCGGAI/V (N-degron) to regulate protein turnover and initiate a protein degradation pathway through an oxygen-sensing mechanism (Gibbs et al., 2014). The ERF-VII proteins not only participate in regulation under hypoxia stress but are also involved in biotic and abiotic stress and hormone response. At the vegetative stage, they enhance the drought-responsive genes expression to recovery from dehydration stress (Fukao et al., 2011).

\subsection{Role of salicylic acid in plant defense response}

Salicylic acid is a phenolic compound and the most common pathway in plants for SA synthesis is, the phenylalanine pathway and isochorismic acid pathway (An C et al., 2011). Most of the research evidence shows that SA can enhance tolerance in plants against various external stresses including salt stress, osmotic stress, chilling, heavy metal stress (Chen YE et al., 2016), and high light by activating the antioxidant system to protect photosynthesis (Gururani MA et al., 2015). SA has a key role in plants to gather hypersensitive response (HR) or systemic acquired resistance and it also modulates various physiological responses such as thermogenesis, ion absorption, and programmed cell death during stress conditions.

\subsection{Role of jasmonic acids in plant defense response}

Jasmonates (JA) are endogenous signaling molecules involved in the various developmental process and also in stress mitigating activities (Llanes A et al., 2016). JA is closely associated with plant resistance to abiotic stress by the physiological and molecular response. Under stress condition, JA alleviates the antioxidant system, accumulation of isoleucine, methionine, soluble sugars (Wasternack C, 2014), regulate the stomatal activities (Acharya BR and Assmann SM, 2009), expression of JA-associated genes (JAZ, AOS1, AOC, LOX2, CO11 ) (Hu YR et al., 2017) and interaction with other phytohormones (Yang J et al., 2019).

\subsection{Role of brassinosteroids in plant defense response}

Brassinosteroids (BRs) are a group of steroidal hormones that play pivotal roles in cell division and elongation, photomorphogenesis, reproductive development, and leaf senescence and also external stress response (Choudhary et al., 2012). BRs increase the activities of catalyzing and decrease the activities of peroxidase and ascorbic acid oxidase under stress conditions (Ahammed et al., 2013) and also regulate secondary metabolites (Vardhini and Rao, 2003).

\subsection{Hormonal crosstalk in plant defense mechanism}

The signaling pathways of different phytohormones are known to interact among themselves in various situations, such as biosynthesis of hormone-responsive transcription factors to regulate plant defense reaction. 
To regulate the balance between seed dormancy and germination, the cross talk of ABA with GA, mediated by DELLAs is a key mechanism for evading early abiotic stress conditions. The signaling pathways of SA and JA are known to interact at various points to regulate the numerous biotic stress antagonistically (Bari R and Jones JD, 2009). Different studies evidenced that SA-facilitated suppression of JA-responsive genes like PDF1.2, LIPOXYGENASE 2 (LOX2), and VEGETATIVE STORAGE PROTEIN (VSP) was abolished in npr1 mutant plants (Spoel SH et al., 2003). Both JA and ET pathways stabilize EIN3 and thus exhibit resistance to necrotrophs (Zhu Z et al., 2011). Auxin associate with ethylene to regulate root development under drought and salinity stress conditions. Furthermore, benzothiadiazole S-methyl ester (BTH), SA analog, treated Arabidopsis suppress the several auxin-responsive genes. SA signaling minimizes the TRANSPORT INHIBITOR RESISTANT 1 (TIR1)/ AUXIN SIGNALING F-BOX (AFB) gene expression (Wang D et al., 2007).

Cytokinins also known to crosstalk with SA and others signaling cascade to regulate plant defenses. For instance, ARABIDOPSIS RESPONSE REGULATOR 2 (ARR2) (cytokinin-activated transcription factor), a type BARR, interacts with TGA3 (bZIP-type transcription factor) and promotes SA defense responses in an NPR1-dependent manner (Choi J et al., 2010). A majority of the time, ABA suppresses the CYTOKINE OXIDASE. ARABIDOPSIS HISTIDINE KINASE (AHKs) functions as cytokinin receptors and regulates drought and salinity response and also ABA signaling, while $A H K 2$ and $A H K 3$ decent osmotic stress response and ABA signaling (Tran LS et al., 2007). ARABIDOPSIS HISTIDINE PHOSPHOTRANSFER PROTEINs (AHPs) negatively control responses to drought stress by losing activity of AHP (

Acute Hepatic Porphyrias) genes resulted in the up-regulation of ABA-responsive genes and thus a strong water stress tolerance phenotype (Nishiyama R et al., 2013).

\section{Hormone functions and cross-talk toward stress tolerance in fruit crops}

\subsection{Hormonal regulation of growth responses under water stress conditions}

Horticulture products are usually sold on a fresh weight basis in the market and yield is predominantly determined by water content (Marcelis et al., 1998). Plants adopted morphological, physiological and biochemical responses and molecular level to mitigate or minimize the effect of drought stress (Conesa et al., 2016). Drought is responsible for the drastic reduction in productivity (Medici et al., 2014). Flooding also produces the same impact as drought on horticulture crops by creating an anaerobic respiration zone around the root (Issarakraisila et al., 2007) and upsurges the soil-borne diseases (Rao and Li, 2003). Thereby, relevant reports about several hormones influence the inflection of water stress in fruit crops that have been produced and some are commented next.

Some studies show that ABA-induced auxin regulates the root growth and root cell differentiation (Xu et al., 2013) and modulate proton secretion at root tips under drought stress condition. Also, ABA-mediated auxin transporter inhibits lateral root growth under moderate water stress conditions (Shkolnik- Inbar and Bar-Zvi, 2010). At the genetic level, ABI3 (ABA insensitive 3) interact with Aux/IAA or ARF proteins and LR growth inhibited in mutants of ABI3 mutants by attenuation of auxin responses. In contrast, $A B I 4$ overexpression harms LR development. Some of the research work provided evidence that drought can affect the expression of core abscisic acid signaling constituents, equivalent to ABA, PYR/PYL/RCAR ABA receptors, subclass III SnRK2 protein kinases and protein phosphatases 2C (PP2C) (Weiner et al., 2010). ABA non-functional mutants are extra vulnerable to drought and salinity as compared to transgenic plants which can induce much hormonal response (Qin and Zeevaart, 2002). PYR/PYL/RCARs, PP2C, SnRK2s, and bZIP transcription are incorporated by the ABA-facilitated signaling pathway during water stress conditions. Zhung et al. (2012) proved thatOsPIN3t, auxin influx carrier involved in drought stress conditions and overexpression of OsPIn3t upregulate drought-responsive genes, OsDREB2A and OsAP37 and improve the tolerance against drought. $\mathrm{ABA}$ is known to regulate the balance between intrinsic growth and external responses. AtABCG25 acts as ABA transporter in cell membrane and export ABA from the cytoplasm to outside of the cell. Reduced transpiration observed when AtABCG25overexpressed. Kuromori et al., (2016) observed that AtABCG25over-expression stimulated a local ABA response in guard cells and 
increase the drought tolerance, probably resulting from the maintenance of water content.

Jasmonic acid also regulates the water loss under drought conditions by regulating stomatal opening and closing (Savchenko T et al., 2014). Jasmonate ZIM-domain proteins (JAZ) are regulators in the JA signaling pathways. OsJAZ1 play a negative role for stress tolerance in rice under drought condition with the ABA and signaling pathways (Fu et al., 2017). Seo et al. (2011) demonstrated that OsbHLH148 acts as a transcriptional regulator and up-regulates OsDREB1 and $O s J A Z$ under dehydration condition. Furthermore, Ge et al. (2010) found that JA accumulation could promote leaf senescence, improve plant survival by preventing excessive water loss. Foliar application of MEJA on soybean plants can improve water stress tolerance with an increase in sugars, phenolic compounds, and flavonoids in leaves (Mohamed HI et al., 2017).

Mango orchids present in the rainfed area can survive for a long period by adopting drought-tolerant mechanisms (Chacko, 1986) and they set fruit when daily average temperature more than $20^{\circ} \mathrm{C}$. But flooding for more than 2 weeks can significantly reduce root dry weight (Larson et al., 1991), net CO2 assimilation, stomatal conductance, and transpiration rate (Schaffer et al., 1992). Grape plants develop large-sized vessels in the xylem to transport water under drought conditions (Serra et al., 2013). Grafting high yielding commercial varieties scions on drought-tolerant rootstocks helps to overcome the water stress (Kodur et al., 2010). Initially ABA concentration is an increase in stressed roots, and later it is transported to the leaves to reduce the photosynthesis and partially transpiration. Pomegranate is considered to be both winter hardy and drought-tolerant plant (Aseri et al., 2008). Mild to severe drought stress during the reproductive stage may reduce the fruit size by $10-50 \%$ in cluster apple. Whereas $50 \mathrm{ppm}$ GA3 application along with wheat straw mulch gave the highest net income (Patel et al., 2010) with good fruit setting during water stress conditions. Custard apples are very sensitive to salt in irrigation water and should not exceed an electrical conductivity of $800 \mu \mathrm{S} / \mathrm{cm}$ (George et al., 1999). Ber plants are comparatively more resilient for water stress by producing pubescent leaves with a large number of stomata arranged in the interveinal regions, whereas the adaxial surface is glabrous, with few comparatively sunken stomata (Clifford et al., 2002). The date palm tree has naturally evolved as drought and salt-tolerant plants through selection (Zaid and deWet, 2002) with an adaptation capacity more than barley for saltwater (Furr and Armstrong, 1975). In litchi, ABA content in leaves increased with the drought (Stern et al., 2003) by inhibited CO2 assimilation in litchi leaves (Damour et al., 2008).

Application of paclobutrazol (gibberellin biosynthesis inhibitor) can induce stress protection in apple (Swietlik and Miller, 1983), strawberry (Navarro et al., 2007), and peach (George and Nissen, 1992) under drought conditions. In flood soil, PM ATPase stimulates the accumulation in putrescine to support cell homeostasis and nutrient acquisition (Bertini et al., 1997) with a reduction in superoxide radicals and $\mathrm{H} 2 \mathrm{O} 2$ accumulation. GA interferes with the ethylene and ABA biosynthesis by upregulating ethylene response factor (ERF) domain proteins SNORKEL1 and SNORKEL2 to minimize the negative effect of excess water (Hattori et al., 2009). During drought, IAR3 (IAA-Ala Resistance3) involved in lateral root production, free auxin production (Kinoshita et al., 2012). It stimulates the gibberellin production and inhibits the ABA synthesis for plant accumulation under submerged conditions (Colebrook et al., 2014). ABA level shows a decrease with an increase in hydration, but PA or DPA levels either increase or remain unaltered (Zhou et al., 2004). ABA restrict their water loss through controlled transpiration (Thompson et al., 2007) and regulates the influx or efflux of $\mathrm{K}+$. The decline in cytokinin concentration under soil moisture deficit conditions observed in grapevines (Satisha et al., 2005) and partial root drying harmed the xylem cytokinin concentration with a distinct increase in xylem sap pH (Stoll et al., 2000). During water stress conditions enhances ethylene production in orange (Ben-Yehoshua and Aloni, 1974), avocado (Adato and Gazit, 1974), and in many other plant species leads to increased senescence of fruits/ leaves and reduced growth. The ethylene production indirectly depends on the magnitude of stress, stress intensity, and stress duration (Upreti et al., 2000).

Under flood, condition roots trigger the ACC synthesis, which later oxidized to ethylene when it reaches shoots and cause nastic movements of the leaves and promote aerenchyma tissue formation to mitigate oxygen deficiency (Colmer, 2003). External application of polyamines ameliorates the drought stress in pomegranate 
by increasing proline concentration (Amri and Mohammadi, 2012) Polyamines stabilize membranes and forming potential of higher buffering and antioxidant capacity (Roy and Sengupta, 2014). The balance of auxin levels (IAA) required for the adaptive recovery growth of litchi plants after release from the stressed environment. Although the levels of cytokinins decreased and levels of ABA increased (Krishna, 2012).

Some signaling molecules include inositol (Sengupta et al., 2008); polyamines (Rangan et al., 2014), and various involved in minimizing the water stress with minimum biomass loss. They may induce the production like protective proteins such as dehydrins; late embryogenesis abundant (LEA) proteins; heat shock proteins (HSPs) (Juszczak and Bartels, 2017). LEA proteins, dehydrin, lipid transfer proteins saturate enzymes, $\mathrm{RAB}$ (responsive to ABA) are associated with the protection of cellular structures (Cushman and Bohnert, 2000). AREB1/ABF2, AREB2/ABF4, and ABF3 like bZIP transcription factors are induced by dehydration, salinity, or ABA treatment under drought condition (Yoshida et al., 2010).

Genomics and crop physiology studies of waters stress provide accurate information to breeders for plant improvement (Tuberosa and Salvi, 2006). Plants have sets of drought regulatory genes, which activated during the water-stress condition to minimize the hassle condition (Wohlbach et al., 2008). In plants at the initial phase of drought, water stress stimulate the production of ABA, which induce the expression of genes (Ding et al., 2016) like, RD29A ,RD29B , KIN2 and RAB18 (Yao et al., 2012),rd22 (Abe et al., 1997) and PYL8 (Lim et al., 2013). SUBA-1 allele induces the negative regulation of ethylene in plants to survive under prolonged submerged condition (Xu et al., 2006). Over-expression of the ESKIMO1 gene in Arabidopsis (Bouchabke-Coussa et al., 2008) and pro biosynthesis gene in Cicer arietinum (Bhatnagar-Mathur et al., 2009) were observed during artificial drought condition. Several transcription studies show, how plants recover after mild drought condition as compared to complete irretrievable inhibition of photosynthesis under severe drought (Watkinson et al., 2003). Most of the time, MYC, MYB, DRE-binding protein (DREB)/ Crepeat-binding factor $(\mathrm{CBF}), \mathrm{ABA}$-binding factor $(\mathrm{ABF})$ and mainly cis-elements $\mathrm{ABA}$-responsive element (ABRE) transcription factors present in ABA biosynthesis cycle are involved in drought stress management (Bartels and Sunkar, 2005).

\subsection{Hormonal regulation of growth responses under high-temperature stress condition}

The temperature has a major influence next to moisture for plant growth and development. In optimum temperature, the plants may grow faster and comes to flowering even earlier than normal. Those plants grown under cool conditions, they produce more upright leaves, but under warm humid conditions, they are more horizontal to downward (Ravi et al., 2013). Under subtropics, banana plant development is slower than in the tropics irrespective of yield and bunch size and they need optimum temperature around $22^{\circ} \mathrm{C}$ and stops growing above $39^{\circ} \mathrm{C}$ and below $10^{\circ} \mathrm{C}$. When temperature crosses the sunburn critical temperature $\left(>38^{\circ} \mathrm{C}\right)$. Pomegranate can tolerate drought by morphological and/or physiological modification which enables them to avoid or postpone desiccation in the semiarid zone (Save et al., 1995). Custard apple normally requires a hot and dry climate during flowering and high humidity for a good fruit setting. Even they can tolerate extreme temperatures (below freezing and up to $40^{\circ} \mathrm{C}$ ). Soil temperatures below $10^{\circ} \mathrm{C}$ may cause severe chilling injury leading to loss of cell membrane stability (Maritza et al., 2004).

Most of the time-temperature in the plant is regulated by the transcription regulators like HSFs by activation of many heat shock responsive genes and heat shock proteins. A large number ofHSFs and Hsps genes are identified in different crops from available genome sequence information and they are involved in heat shock regulatory network (Hu et al., 2009). There are $25 \mathrm{HSFs}, 29 s H s p s, 26 \mathrm{Hsp} 70$, 9 Hsp90 , and 10 Hsp 100 family genes that were identified in rice crop, 35 DcHCFs in carrot, $21 \mathrm{HSFs}$ in Arabidopsis thaliana, 28 in Populus trichocarpa , 16 in Medicago truncatula , 52 inBrassic rapa, 25 in Zea mays, and 26 in Glycinemax , respectively (Huang et al., 2015). When temperature crossed $45^{\circ} \mathrm{C}$, the $H s f A 1$ gene activated in the tomato plant to minimize the impact of high temperature (Mishra et al., 2002). Whereas, Hsp101 (mitochondrial transcription termination factor-related protein) in Arabidopsis enhanced the thermo-tolerance via mitochondrial oxidative damage control (Kim et al., 2012). Nearly $5 \%$ of transcriptomic activity observed and chaperones conquer only a minor part during heat stress conditions (Larkindale and Vierling, 2008). They mainly involved in metabolism of calcium and phytohormone signaling protein phosphorylation (Saidi 
et al., 2011). For maintaining photosynthesis and transpiration under stress conditions, Chloroplast protein synthesis transcription factor accumulation is mandatory (Ristic et al., 2008). Under high-temperature stress condition, polycationic nature of polyamines stabilize the membrane structural integrity and facilitates their strong binding to nucleic acids, proteins, and membranes (Childs et al., 2003).

\subsection{Hormonal regulation of growth responses under chilling stress condition}

Low-temperature (chilling) stress may causes dehydration in plants by limiting water uptake and stomatal activities (Mahajan and Tuteja, 2005). Plants differ in their response to chilling $\left(0-15^{\circ} \mathrm{C}\right)$ and freezing $(<$ $0^{\circ} \mathrm{C}$ ) (Xin and Browse, 2001). In general, initially chilling symptoms appear in the cell membrane by forming flexible liquid crystalline cell membranes into a solid gel phase (Farooq et al., 2009). Whereas in fruit crops, chilling may cause a delay in fruit ripening and fruit deformation. Low temperature during storage may cause browning, reddening, woolliness, and mummification (Lurie and Crisosto, 2005). Incidence of frost during fruit development forms ice crystals in subcellular space and damages the plant cell activities, in severs condition, complete plant death may also occur (Levitt, 1980). The intensity of frost damage also depends on the physiological condition of plants (Proebsting and Mills, 1978). It affects cell membrane integrity, ion leakage, biomolecule activities, and gene expression (Dhanapal and Crisosto, 2013). In fruit crops, chilling can suppress the photosynthesis by reducing photosystem II efficiency (Allen et al., 2000). Different phytohormones have a role in cold stress is yet to be discussed in detail.

ABA acts as a messenger in the regulation of water level in plants (Mahajan and Tuteja, 2005). Same as ABA, auxins involved in defense response against abiotic stresses in plants (Wolters and Jurgens, 2009). It more intricately involved in the various developmental process like fruit development, root initiation in grafting, root growth, and development (Depuydt and Hardtke, 2011). Members of the auxin-responsive GH3 gene family also has cold stress-responsive activities. OsGH3-2 found to modulate both endogenous free IAA and ABA homeostasis and differentially affect cold tolerance in rice (Du et al., 2012). However, the role of auxin remains unclear under stress conditions in fruit crops. Brassinosteroids avoid ions leakage in chilled stressed rape seeds (Janeczko et al., 2007), whereas it improves the antioxidant defense in young grapevines to avoid the negative impact of cold stress (Xi et al., 2013) by biosynthesis of de novo or activation of enzymes (Bajguz, 2000). When chilling sensitive banana plants were treated with SA (0.5mM) caused an increase in SOD, CAT, and APX activities when plants are induced to very low temperature (Kang et al., 2003). Wang and Li (2006) also showed that SA treated grapevines decreased lipid peroxidation and electrolyte leakage and induced cold tolerance.

GA also plays an important role in the low-temperature condition. It enhances the bolting and flowering in Limonium gmelinii plants when GA sprayed at $500 \mathrm{mg} \mathrm{L}-1$ (Guda et al., 2000). GA inhibits the sucrose formation from starch and mannitol (Ogasawara et al., 2001). This outcome suggests that the GA application enhances the rapid tissue enlargement and differentiated to resist the cold stress in plants (Jacobsen and Olszewski, 1993). Chilling causes discoloration to the peel of the ripened fruit by coagulating latex in latex ducts. The exogenous application of methyl jasmonate enhanced soluble protein and antioxidant content under cold stress in banana plants (Zhao et al., 2013). Cold stress also enhances the ethylene biosynthesis (Zhao et al., 2014). Zhao et al. (2009) reported that ethylene levels in plants and cold tolerance are positively correlated up to a certain level.

Chilling can induce the expression of jasmonic acid biosynthesis genes, including allene oxide synthase (AOS1 ), oxide cyclase $(A O C)$, and lipoxygenase ( $L O X 2$ ). Recent studies show that, in banana, two MYC2 TFs are activated following the exogenous application of MeJA in the cold storage condition and enhances the expression of an inducer of CBF expression (ICE-CBF) cold-sensitive pathways genes (Zhao ML et al., 2013). In MeJA induce chilling tolerance, the MaMYC2 transcription factor in coordination withMaICE1 reduces lipoxygenase activity and increases antioxidant synthesis. Cao et al. (2009) found that ascorbate peroxidase $(A P X)$, catalase $(C A T)$ and superoxide dismutase $(S O D)$ activities in MeJA treated loquat fruits.

To manage the chilling injury, SA and MeSA treatments are given, which are easy to set up, less expansive, and applicable to any crops. They increase the AOX transcript level and reduces the chilling incidence. 
When plants are treated with SA and MeSA before chilling induces the HSPs biosynthesis and increases the tolerance against chilling injury (Ding et al., 2001). Different genetic studies show that many auxinresponsive genes are involved in cold stress (Jain and Khurana, 2009). Likewise, PIN1 and PIN3, an auxin transporter mediate root gravity response during the early phase is inhibited by cold stress (Shibasaki et al., 2009). Zhao et al. (2009) in tomato found a positive relationship between ethylene and freezing tolerance from the negative effects of 1-methyl cyclopropene, which inhibit ethylene biosynthesis on freezing tolerance. For freezing tolerance, the RARE COLD INDUCIBLE 1A ( $R C I 1 A)$ gene interacts with ACC synthase. Dehydration-responsive element-binding proteins/C-repeat binding factors (DREBs/CBFs ) interact with dehydration-responsive elements/C-repeat-elements $(D R E / C R T)$ to execute a highly coordinated transcriptional response to cold signals. C-repeat-binding factors $(C B F)$ cold response pathway is found in freezing-tolerant (FT) plants (Skinner et al., 2005) and in freezing-sensitive (FS) plants (Zhang et al., 2004).

\subsection{Hormonal regulation of growth responses under salinity stress condition}

Soil salinity induced by excessive accumulation of sodium chloride ( $\mathrm{NaCl}$ ) (Munns and Tester, 2008). When salt content in irrigation water crossed the threshold level may harm osmotic adjustment, ion uptake, osmotic adjustment, photosynthesis, stomatal conductance, protein synthesis, nucleic acid production, enzymatic activity, and hormonal stability (Raga et al., 2016). Based on salt stress tolerance potential, plants have been classified into two major groups; i) halophytes have the potential to survive and reproduce even when salt concentration nearly $200-\mathrm{mM} \mathrm{NaCl}$ and ii) glycophytes are not able to survive under salt stress condition (Patane et al., 2013). Glycophytes produce stress symptoms like decreased in total leaf area and leaf growth, marginal and tip yellowing and tip scorching, marginal and tip scorching of leaves, yellowing and bronzing, early leaf drop, twig dieback, blackening, necrosis, and leaf burning (Bernstein et al., 2004). Structural disorders were found in both sensitive and tolerant genotypes, such as an increase in leaf thickness, excessive chloride accumulation with reduced Mg2+, and loss of chlorophyll content (Aranda et al., 1998).

Osmotic regulation is one of the most important mechanisms to avoid osmotic stress by accumulating metabolites like glycine, betaine, proline, mannitol, and soluble sugars (Houimli, 2010). Morphologically some level of salinity stress can be minimized in fruit crops by grafting of salt-sensitive improved high yielding cultivars on salt tolerance rootstocks (Munns et al., 2006). Under mid salinity stress, reduction in lateral root (LR) elongation and an increase in the number of LRs observed. Besides, the reduction of LRs numbers observed in auxin signaling mutants axr1, axr 4, and tir1 completely blocked auxin influx (Zolla et al., 2010). Even at low salt stress can suppress auxin efflux carrier PIN2 and also decrease thePIN2 : GFP concentration in root tips. It suggests that salt regulates both transcription and posttranscriptional activities (Zhao et al., 2011). High salt concentration causes rapid degradation of amyloplasts in root columella cells thereby reduce the gravity response in roots (Sun et al., 2008). The development of LRs by salt overly sensitive 3 (SOS3 ) under salinity stress conditions has been reported by auxin redistribution activities (Zhao et al., 2011). Mutants of SOS3 do not accumulate auxin in plant aerial parts. The NAC transcription factors have a key role in plant growth and stress responses. NAC1 and NAC2 proteins promote lateral root formation in Arabidopsis. AtNAC2 gene expression was induced by auxin, ethylene, and ABA. Under salt stress condition auxin receptor mutants tir1 suppressed. Nacl also downregulate TIR1 expression (Xie, 2000)

When rootstocks of Microhyla zeylanica are used to cultivate mango under $60-\mathrm{mM} \mathrm{NaCl}$ salinity condition, plants maintained a higher photosynthetic rate with greater $\mathrm{K}+/ \mathrm{Na}+$ ratio in roots and lesser in leaf/root $\mathrm{Na}+$ (Schmutz, 2000). Whereas Pistacia atlanticarootstock gave the better result as compared to Polycythemia verarootstock when used in pistachio plants under salinity stress (Tounsi et al., 2017). External application of 30-mM/L calcium nitrate for citrus plants significantly reduced $\mathrm{Cl}$ and $\mathrm{Na}+$ uptake by the root system and also enhanced the growth attributes and gaseous exchange mechanism (Banuls et al., 1997). In olive plants, a reduction in stomatal conductance and photosynthesis observed when soil $\mathrm{NaCl}$ content crossed the $100 \mathrm{mM}$ level (Tabatabaei, 2006). Jujube plants have more potential to resist salinity compared to other cultivated fruit crops, in which two wild Indian jujube (Ziziphus rotundifolia and Ziziphus nummularia ) were found to be more resistant to saline conditions due to higher stomatal conductance, higher $\mathrm{CO} 2$ assimilation, higher hormonal regulation, antioxidants accumulation and better nutrients translocation 
(Meena et al., 2003) by accumulating high amount of $\mathrm{Na}+$ in roots through restricted translocation and high $\mathrm{K}+/ \mathrm{Na}+$ ratio to keep ionic balance in leaves (Mohammadkhani, 2018). Number fruit crops are identified which can store excess $\mathrm{K}+$ in leaf, stem and other tissues to mitigate the negative effect of Salinity. The lowest $\mathrm{Cl}$ ion concentration and high $\mathrm{K}+$ were recorded in lemon (Gimeno et al., 2009) and fig (Zarei et al., 2016) plants when these plants are irrigated with water containing $50-\mathrm{mM} \mathrm{NaCl}$ with $10-\mathrm{mM}$ potassium nitrate. Arbuscular mycorrhiza like fungi can increase the stress tolerance potential in trifoliate orange by accumulating a low amount of $\mathrm{Na}+$ and $\mathrm{Ca} 2+$ while higher $\mathrm{K}+$, proline content, and carbohydrate content.

Proline can help to store carbon and nitrogen and maintains the structural integrity of cell membranes and proteins by purifying free radicals (Jalili et al., 2009) and it maintains the buffering capacity of cells against salinity (Heidari, 2012). Fozouni et al. (2012) demonstrated that Vitis vinifera table grape significantly increases the proline accumulation with increased salinity. But it harms photosynthesis by degrading chlorophyll content (Behboudian et al., 1986). The optimum value for the soil $\mathrm{K} / \mathrm{Na}$ is 2.5 for the banana if this proportion exceeds by $8 \%$ can cause economic loss. Salt tolerant fruit crops have succulent organs, salt exclusion, excretion of salts, and accumulation of ions in the tonoplasts to maintain osmatic regulation. Pomegranate tissues can accumulate sodium, chlorine, and potassium ions without any stress symptoms in response to saline water irrigation and it can tolerate salinity up to $40 \mathrm{mM} \mathrm{NaCl}$ but at higher $\mathrm{NaCl}$ concentration $(>40 \mathrm{mM})$ affects the main stem length, number of internodes and the leaf surface area (Naeini et al., 2006) and decrease in soluble sugar accumulation was observed (Naeini et al., 2004). Date palm plants are considered as one of the exceptional halophytic plants and it can survive under severe salt stress conditions. Ramoliya and Pandey (2003) found that some datepalm cultivars adopted salt exclusion mechanisms and they can endure high soil salinity levels (up to $12.8 \mathrm{dS} \mathrm{m}-1$ ) with no visible effect on the seedlings (Greenway and Munns, 1980). Litchi trees should not be irrigated with water with salt contains more than 0.5 dS per m electric conductivity. If salinity level exceeds, symptoms like tips and margins die were observed in old leaves also.

When chloride content in plants crossed the toxic level induce the production of ethylene precursor ACC, leads to leaf senescence. In counteract to ethylene activities, plants trigger the biosynthesis of ABA to reduce ethylene production (Arbona et al., 2006). Silver thiosulfate and phosgene synthetics are also used externally to inhibit the ethylene lead senesce in salt-affected plants. The same result were observed in a grapevine, where the extreme rise in ABA level observed in resistant cultivars rootstock when planted in salt stress soil (Upreti and Murti, 2010). Olive plants that are grown under salinity, water uptake, relative water uptake, and water potential drastically reduced (Chartzoulakis, 2005; Yadav et al., 2011).

GA3 application increase the nutrient uptake, plant height, and yield in wheat (Ashraf et al., 2002) and rice (Wen et al., 2010) when cultivated under saline condition. Different plants can tolerate salt stress with increasing GA concentration by more absorption of $\mathrm{P}$ and $\mathrm{Ca} 2+$ and less absorption of $\mathrm{Na}+$ (Starck and Kozinska, 1980), stomatal resistance and enhanced plant water use were observed at low salinity in tomato (Maggio et al., 2010) and it enhances the catabolism of ABA (Gonai et al., 2004). The GA metabolism and signaling play a major role in plant physiological adaptation, low-temperature influences of bioactive GA as a result of an increase in expression of three GA2ox genes (Archard et al., 2008). Rootstocks of grapes with high cytokinin can maintain a high $\mathrm{K}-\mathrm{Na}$ ratio and root-shoot dry mass ratio under salinity (Upreti and Murti, 2010). In desert almond trees, cytokinin concentration peak in the morning time and rapid decline in the afternoon based on the stomatal conductance (Fusseder et al., 1992). Brault and Maldiney (1999) reported that cytokinins act at the plasma membrane along with other signaling compounds.

An important role of ethylene in salt tolerance by relating its ability to retain $\mathrm{K}+$ without decreasing $\mathrm{Na}$ in roots as well as in shoots (Yang et al., 2013) and It stimulates H+-ATPase activity to modulate ion homeostasis (Wang et al., 2009). Polyamine content in the grafted plant increased against salt stress by Prompting superoxide dismutase, peroxidase, and ascorbic peroxidase and glutathione reductase enzyme activities. Upreti and Murti (2010) found a significant increase in polyamines concentration intolerant grape rootstock roots by salinity stress along with $\mathrm{ABA}$ and it helped to maintain the high root- shoot biomass ratio and high K-Na ratio. Similarly, Anjum (2008) reported that Cleopatra mandarin and citrus rootstock 
shows better growth and chlorophyll efficiency at high spermine and carbohydrates with low chloride ions in leaves and roots under salinity. Polyamines control the $\mathrm{Ca} 2+$ allocation through regulating $\mathrm{Ca} 2+$ permeable channels and CAXs by the prevention of $\mathrm{Na}+/ \mathrm{K}+$ entry into the cytoplasm and enhancement of $\mathrm{Na}+/ \mathrm{K}+$ influx to the vacuole with suppression of $\mathrm{Na}+/ \mathrm{K}+$ release from the vacuole. Polyamines regulate the physiology stomata similar to ABA, by targeting KAT1-like inward K+ channel in guard cells of stomata (Liu et al., 2000).

Klingler et al. (2010) suggested that ABA-dependent amino oxidase derived $\mathrm{H} 2 \mathrm{O} 2$ affected stomatal physiology in grapevines. By genetic modification or exogenous application of polyamines enhances salt tolerance in grape (Farooq et al., 2009). In Neo-Muscat grapes seedling significantly accumulate putrescine during osmotic and salt stress by temporary induction of arginine decarboxylase (pVvADC) gene followed by spermine synthase (pVvSPMS) (Liu et al., 2012). The overexpression ofOsGSTU4, an auxin-responsive GSTgene enhance the tolerance to salinity and oxidative stress condition in Arabidopsis plants (Jain et al., 2010).

\subsection{Hormonal regulation of growth responses under heavy metal stress condition}

No organic life can develop and persist without the involvement of metal ions in this universe. The essential microelements for plants are $\mathrm{Cu}, \mathrm{Zn}, \mathrm{Fe}, \mathrm{Mn}, \mathrm{Mo}, \mathrm{Ni}$, and Co whose uptake in excess to the plant causes toxic effects (Monni et al., 2000). $\mathrm{Fe}, \mathrm{Cu} \mathrm{Cr}$, and $\mathrm{Co}$ are involved in a redox reaction, whereas $\mathrm{Zn}, \mathrm{Cd}, \mathrm{Ni}$, $\mathrm{Al}$, etc. monitor the various enzymatic activities in plant cells. Transition metals such as copper and iron have frequently unpaired electrons and are, therefore, very good catalysts of oxygen reduction. Currently, the contamination of the natural ecosystem by these heavy metals represents a global threat, endangering the agriculture ecosystem (Mico et al., 2006). In trace, these elements are essential for normal plant growth and development and play a key role in metabolism by activating different enzymatic activities (Roy and Mcdonald, 2015). However, when the concentration of these metals crossed threshold level cause a negative impact on physiology and biochemistry of plants (Ivanov et al., 2016) and reduce the biomass accumulation in plants (Ebbs et al., 2015) as a result dwindle the photosynthesis rate (Rodriguez et al., 2012), mineral nutrition uptake (Vernay et al., 2007) and communication with water. Besides they can also cell toxicity by excess production of ROS, which impaired antioxidant activities and causes severe oxidative stress (Rui et al., 2016).

Previous research has shown that the application of plant growth-promoting phytohormones can improve protection by counterbalancing heavy metal toxicity in plants (Masood et al., 2016). ABA concentration increase as plants is exposed to heavy metals (Rauser and Dumbroff, 1981). Heavy metals like Zn, Al, Ni, and Cd (Fediuc et al., 2005) have been revealed to raise in ABA level in plants. Hsu and Kao, (2003) reported that at high temperature $\left(30 / 35^{\circ} \mathrm{C}\right), \mathrm{ABA}$ regulates and increase the resistance against $\mathrm{Cd}$ in rice seedlings. It's proven that ABA-mediated the Cd-precipitated stimulation of O-acetylserine (OASTL), the enzyme responsible for cysteine biosynthesis. The expression of ABA and drought resistance BjCdR9 (an aldehyde dehydrogenase) and BjCd55 (RNA binding protein) genes stimulated by Cd in Brassica Juncea supported the involvement of ABA signal transduction and these genes denoting aquaporins PIP 1 and PIP2 was found to be transcribed when exposed to Cd stress. The above observation gave information that water stress is imposed by cd and that ABA and Cd show the synergistic relationship (Fusco et al., 2005). When plants are treated with $\mathrm{ABA}$, both $\mathrm{BjCd} 15$ and TGA3 responded to ABA. However, TGA shows more response to ABA as compared to BjCdR15 (Farinati et al., 2010).

Zhao et al. (2016) observed that Cd concentration increased in roots and leaves at a higher dose of $\mathrm{CdCl} 2$ in JA- deficient tomato mutants. The result shows that a lack of JA biosynthesis enhances the sensitivity against Cd. According to Sirhindi et al., (2015), the exogenous application of JA enhance the tolerance to $\mathrm{NiCl} 2$ in soybean seedlings and it regulates the antioxidant activities to neutralize the heavy metal stress at the cellular level in plants, while Azeem U et al., (2018) revealed that exogenous JA application increases the biomass production and protein concentration in Ni-treated plants and minimize the CD accumulation rate by enhancing osmotic and antioxidant activities, but also inhibiting $\mathrm{H} 2 \mathrm{O} 2$ and Malondialdehyde accumulation (Noriega $\mathrm{G}$ et al., 2012). JA inhibit the peroxidase activity by activating ascorbate or glutathione antioxidant machinery. Such findings reports show that JA plant responses by inducing antioxidant system. 
Although these research reports suggest that phytohormones responsive genes are differentially expressed under various abiotic stress conditions, further indicating/corroborating crosstalk between plant bio-stimulants and abiotic stress signalling.

\section{Conclusion and future prospectus}

Environmental stresses can significantly reduce the yield potential and shift in cultivation area may occur for commercially important fruit crops by climate change. Now need to improve the biosynthesis and utilization of phytohormones without any negative impact by genetic modification in fruit crops to improve tolerance against abiotic stresses. Recently, much attention has been given to the development of strategies designed for breeding to alleviate the adverse effects of abiotic stress by using different phytohormones, from the foregoing research works discussion it is clear that plants utilize elaborate signaling pathways in response to various abiotic stresses. In addition to ROS, antioxidants, and other biochemicals, plant hormones trigger specific signal cascades upon abiotic perception. The vacillation in several key hormone levels and crosstalk among phytohormones occur as early response to stresses. Such crosstalk at the hormonal level in plants helps to integrate various stress signaling pathways. The enhanced level of tolerance to environmental stress at the molecular level by adjusting growth factors is the key role to the plant survival. These have been illustrated in the present review with appropriate research results drawn from the abiotic and biotic stress responses in fruit crops.

\section{Conflict of Interest:}

We declare that, we have no known competing financial interests or personal relationships that could have appeared to influence the work reported in this paper.

\section{References:}

Abe, H., Yamaguchi-Shinozaki, K., Urao, T., Iwasaki, T., Hosokawa, D., \& Shinozaki, K. (1997). Role of Arabidopsis MYC and MYB homologs in drought-and abscisic acid-regulated gene expression. The Plant Cell, 9(10), 1859-1868. doi.org/10.1105/tpc.9.10.1859

Achard, P., \& Genschik, P. (2009). Releasing the brakes of plant growth: how GAs shutdown DELLA proteins. Journal of experimental botany, 60(4), 1085-1092. doi.org/10.1093/jxb/ern301

Achard, P., Gong, F., Cheminant, S., Alioua, M., Hedden, P., \& Genschik, P. (2008). The cold-inducible CBF1 factor-dependent signaling pathway modulates the accumulation of the growthrepressing DELLA proteins via its effect on gibberellin metabolism. The Plant Cell, 20(8), 2117-2129. doi.org/10.1105/tpc.108.058941

Acharya, B. R., \& Assmann, S. M. (2009). Hormone interactions in stomatal function. Plant molecular biology, 69(4), 451-462. doi: 10.1007/s11103-008-9427-0

Adato, I., Gazit, S., \& Blumenfeld, A. (1976). Relationship between changes in abscisic acid and ethylene production during ripening of avocado fruits. Functional Plant Biology, 3(4), 555-558. doi.org/10.1071/PP9760555

Ahammed, G. J., Choudhary, S. P., Chen, S., Xia, X., Shi, K., Zhou, Y., \& Yu, J. (2013). Role of brassinosteroids in alleviation of phenanthrene-cadmium co-contamination-induced photosynthetic inhibition and oxidative stress in tomato. Journal of experimental botany, 64(1), 199-213. doi.org/10.1093/jxb/ers323

Ainley, W. M., Sastry-Dent, L., Welter, M. E., Murray, M. G., Zeitler, B., Amora, R., .. \& \& Simpson, M. A. (2013). Trait stacking via targeted genome editing. Plant Biotechnology Journal, 11(9), 1126-1134. doi.org/10.1111/pbi.12107

Allen, G. J., Chu, S. P., Schumacher, K., Shimazaki, C. T., Vafeados, D., Kemper, A., .. \& \& Chory, J. (2000). Alteration of stimulus-specific guard cell calcium oscillations and stomatal closing in Arabidopsis det3 mutant. Science, 289(5488), 2338-2342. doi: 10.1126/science.289.5488.2338 
Amri, E., \& Mohammadi, M. J. (2012). Effects of timing of drought stress on pomegranate seedlings (Punica granatum L. cv Atabaki) to exogenous spermidine and putrescine polyamines. African Journal of Microbiology Research, 6(25), 5294-5300. doi: org/10.5897/AJMR11.1355

An, C., \& Mou, Z. (2011). Salicylic acid and its function in plant immunity F. Journal of integrative plant biology, 53(6), 412-428. doi: org/10.1111/j.1744-7909.2011.01043.x

Anjum, M. A. (2008). Effect of $\mathrm{NaCl}$ concentrations in irrigation water on growth and polyamine metabolism in two citrus rootstocks with different levels of salinity tolerance. Acta Physiologiae Plantarum, 30(1), 43. doi: 10.1007/s11738-007-0089-3

Arbona, V., López-Climent, M. F., Mahouachi, J., Pérez-Clemente, R. M., Abrams, S. R., \& Gomez-Cadenas, A. (2006). Use of persistent analogs of abscisic acid as palliatives against salt-stress induced damage in citrus plants. Journal of Plant Growth Regulation, 25(1), 1-9. doi.org/10.1007/s00344-005-0038-6

Aseri, G. K., Jain, N., Panwar, J., Rao, A. V., \& Meghwal, P. R. (2008). Biofertilizers improve plant growth, fruit yield, nutrition, metabolism and rhizosphere enzyme activities of pomegranate (Punica granatum L.) in Indian Thar Desert. Scientia horticulturae, 117(2), 130-135. https://doi.org/10.1016/j.scienta.2008.03.014

Ashraf, M. Y., Sarwar, G., Ashraf, M., Afaf, R., \& Sattar, A. (2002). Salinity induced changes in $\alpha$ amylase activity during germination and early cotton seedling growth. Biologia Plantarum, 45(4), 589-591. https://doi.org/10.1023/A:1022338900818

Asins, M. J. (2002). Present and future of quantitative trait locus analysis in plant breeding. Plant breeding, 121(4), 281-291. https://doi.org/10.1046/j.1439-0523.2002.730285.x

Azevedo, R. A., Gratao, P. L., Monteiro, C. C., \& Carvalho, R. F. (2012). What is new in the research on cadmium-induced stress in plants?. Food and Energy Security, 1(2), 133-140. https://doi.org/10.1002/fes3.10

Azim, A. A., Simon, K. M. R., Fino, D., \& Bochmann, G. (2018). The physiological effect of heavy metals and volatile fatty acids on Methanococcus maripaludis S2. Biotechnology for biofuels, 11(1), 301. https://doi.org/10.1186/s13068-018-1302-x

Bai, M. Y., Fan, M., Oh, E., \& Wang, Z. Y. (2012). A triple helix-loop-helix/basic helix-loop-helix cascade controls cell elongation downstream of multiple hormonal and environmental signaling pathways in Arabidopsis. The Plant Cell, 24(12), 4917-4929. DOI: https://doi.org/10.1105/tpc.112.105163

Bajguz, A. (2000). Effect of brassinosteroids on nucleic acids and protein content in cultured cells of Chlorella vulgaris. Plant Physiology and Biochemistry, 38(3), 209-215. https://doi.org/10.1016/S0981-9428(00)007336

Banerjee, A., \& Roychoudhury, A. (2019). The regulatory signaling of gibberellin metabolism and its crosstalk with phytohormones in response to plant abiotic stresses. In Plant signaling molecules (pp. 333339). Woodhead Publishing. https://doi.org/10.1016/B978-0-12-816451-8.00020-4

Bañuls, J., Serna, M. D., Legaz, F., Talon, M., \& Primo-Millo, E. (1997). Growth and gas exchange parameters of Citrus plants stressed with different salts. Journal of Plant Physiology, 150(1-2), 194-199. https://doi.org/10.1016/S0176-1617(97)80202-7

Bari, R., \& Jones, J. D. (2009). Role of plant hormones in plant defence responses. Plant molecular biology, 69(4), 473-488. DOI 10.1007/s11103-008-9435-0

Bartels, D., \& Sunkar, R. (2005). Drought and salt tolerance in plants. Critical reviews in plant sciences, 24(1), 23-58. https://doi.org/10.1080/07352680590910410

Behboudian, M. H., Walker, R. R., \& Törökfalvy, E. (1986). Effects of water stress and salinity on photosynthesis of pistachio. Scientia Horticulturae, 29(3), 251-261. https://doi.org/10.1016/0304-4238(86)90068-3 
Belhaj, K., Chaparro-Garcia, A., Kamoun, S., \& Nekrasov, V. (2013). Plant genome editing made easy: targeted mutagenesis in model and crop plants using the CRISPR/Cas system. Plant methods, 9(1), 1-10. https://doi.org/10.1186/1746-4811-9-39

Ben-Yehoshua, S., \& Aloni, B. (1974). Effect of water stress on ethylene production by detached leaves of Valencia orange (Citrus sinensis Osbeck). Plant Physiology, 53(6), 863-865. https://doi.org/10.1104/pp.53.6.863

Bernstein, N., Meiri, A., \& Zilberstaine, M. (2004). Root growth of avocado is more sensitive to salinity than shoot growth. Journal of the American Society for Horticultural Science, 129(2), 188-192. https://doi.org/10.21273/JASHS.129.2.0188

Bertini, I. (1997). Determinants of reduction potentials in metalloproteins. JBIC Journal of Biological Inorganic Chemistry, 2(1), 108-108. https://doi.org/10.1007/s007750050112

Bhatnagar-Mathur, P., Devi, M. J., Vadez, V., \& Sharma, K. K. (2009). Differential antioxidative responses in transgenic peanut bear no relationship to their superior transpiration efficiency under drought stress. Journal of Plant Physiology, 166(11), 1207-1217. https://doi.org/10.1016/j.jplph.2009.01.001

Bouchabke, O., Chang, F., Simon, M., Voisin, R., Pelletier, G., \& Durand-Tardif, M. (2008). Natural variation in Arabidopsis thaliana as a tool for highlighting differential drought responses. PLoS one, 3(2), e1705. https://doi.org/10.1371/journal.pone.0001705

Bouchabke-Coussa, O., Quashie, M. L., Seoane-Redondo, J., Fortabat, M. N., Gery, C., Yu, A., .. \& DurandTardif, M. (2008). ESKIMO1 is a key gene involved in water economy as well as cold acclimation and salt tolerance. BMC plant biology, 8(1), 125.

Brault, M., \& Maldiney, R. (1999). Mechanisms of cytokinin action. Plant Physiology and Biochemistry, 37(5), 403-412. https://doi.org/10.1016/S0981-9428(99)80046-1

Bray, E. A. (2002). Abscisic acid regulation of gene expression during water-deficit stress in the era of the Arabidopsis genome. Plant, cell \& environment, 25(2), 153-161. https://doi.org/10.1046/j.13653040.2002.00746.x

Bray, W. (1995). Searching for environmental stress: climatic and anthropogenic influences on the landscape of Colombia. Archaeology in the Lowland American Tropics: Current Analytical Methods and Applications, Cambridge University Press, Cambridge, UK, 96-112.

Brodersen, P., Petersen, M., Bjorn Nielsen, H., Zhu, S., Newman, M. A., Shokat, K. M., .. \& Mundy, J. (2006). Arabidopsis MAP kinase 4 regulates salicylic acid-and jasmonic acid/ethylene-dependent responses via EDS1 and PAD4. The Plant Journal, 47(4), 532-546. https://doi.org/10.1111/j.1365-313X.2006.02806.x

Browse, J., \& Xin, Z. (2001). Temperature sensing and cold acclimation. Current opinion in plant biology, 4(3), 241-246. https://doi.org/10.1016/S1369-5266(00)00167-9

Burbidge, A., Grieve, T. M., Jackson, A., Thompson, A., McCarty, D. R., \& Taylor, I. B. (1999). Characterization of the ABA-deficient tomato mutant notabilis and its relationship with maize Vp14. The Plant Journal, 17(4), 427-431. https://doi.org/10.1046/j.1365-313X.1999.00386.x

Cao, P., Song, J., Zhou, C., Weng, M., Liu, J., Wang, F., .. \& Wang, B. (2009). Characterization of multiple cold induced genes from Ammopiptanthus mongolicus and functional analyses of gene AmEBP1. Plant molecular biology, 69(5), 529. DOI 10.1007/s11103-008-9434-1

Chacko, E.K., 1986. Physiology of vegetative and reproductive growth in mango (Mangifera indica L. ) trees. In: Proc. 1 st Australian Mango Research Workshop, 1984, Cairns, Qld., Australia, CSIRO, Melbourne, Vic., pp. 54-70.

Chartzoulakis, K. S. (2005). Salinity and olive: growth, salt tolerance, photosynthesis and yield. Agricultural Water Management, 78(1-2), 108-121. https://doi.org/10.1016/j.agwat.2005.04.025 
Chen, Y. E., Cui, J. M., Li, G. X., Yuan, M., Zhang, Z. W., Yuan, S., \& Zhang, H. Y. (2016). Effect of salicylic acid on the antioxidant system and photosystem II in wheat seedlings. Biologia plantarum, 60(1), 139-147. https://doi.org/10.1007/s10535-015-0564-4

Cheong, Y. H., Chang, H. S., Gupta, R., Wang, X., Zhu, T., \& Luan, S. (2002). Transcriptional profiling reveals novel interactions between wounding, pathogen, abiotic stress, and hormonal responses in Arabidopsis. Plant physiology, 129(2), 661-677. DOI: https://doi.org/10.1104/pp.002857

Chernys, J. T., \& Zeevaart, J. A. (2000). Characterization of the 9-cis-epoxycarotenoid dioxygenase gene family and the regulation of abscisic acid biosynthesis in avocado. Plant physiology, 124(1), 343-354. DOI: https://doi.org/10.1104/pp.124.1.343

Childs, A. C., Mehta, D. J., \& Gerner, E. W. (2003). Polyamine-dependent gene expression. Cellular and Molecular Life Sciences CMLS, 60(7), 1394-1406. https://doi.org/10.1007/s00018-003-2332-4

Choi, J., Huh, S. U., Kojima, M., Sakakibara, H., Paek, K. H., \& Hwang, I. (2010). The cytokinin-activated transcription factor ARR2 promotes plant immunity via TGA3/NPR1-dependent salicylic acid signaling in Arabidopsis. Developmental cell, 19(2), 284-295. https://doi.org/10.1016/j.devcel.2010.07.011

Choudhary, S. P., Yu, J. Q., Yamaguchi-Shinozaki, K., Shinozaki, K., \& Tran, L. S. P. (2012). Benefits of brassinosteroid crosstalk. Trends in plant science, 17(10), 594-605. https://doi.org/10.1016/j.tplants.2012.05.012

Claeys, H., Skirycz, A., Maleux, K., \& Inze, D. (2012). DELLA signaling mediates stress-induced cell differentiation in Arabidopsis leaves through modulation of anaphase-promoting complex/cyclosome activity. Plant physiology, 159(2), 739-747. DOI: https://doi.org/10.1104/pp.112.195032

Clifford, S. C., Arndt, S. K., Popp, M., \& Jones, H. G. (2002). Mucilages and polysaccharides in Ziziphus species (Rhamnaceae): localization, composition and physiological roles during drought-stress. Journal of experimental Botany, 53(366), 131-138. https://doi.org/10.1093/jexbot/53.366.131

Colebrook, E. H., Thomas, S. G., Phillips, A. L., \& Hedden, P. (2014). The role of gibberellin signalling in plant responses to abiotic stress. Journal of experimental biology, 217(1), 67-75. doi: 10.1242/jeb.089938

Collard, B. C., Jahufer, M. Z. Z., Brouwer, J. B., \& Pang, E. C. K. (2005). An introduction to markers, quantitative trait loci (QTL) mapping and marker-assisted selection for crop improvement: the basic concepts. Euphytica, 142(1-2), 169-196. https://doi.org/10.1007/s10681-005-1681-5

Colmer, T. D. (2003). Long-distance transport of gases in plants: a perspective on internal aeration and radial oxygen loss from roots. Plant, Cell \& Environment, 26(1), 17-36. https://doi.org/10.1046/j.13653040.2003.00846.x

Conesa, M. R., De La Rosa, J. M., Domingo, R., Banon, S., \& Perez-Pastor, A. (2016). Changes induced by water stress on water relations, stomatal behaviour and morphology of table grapes (cv. Crimson seedless) grown in pots. Scientia Horticulturae, 202, 9-16. https://doi.org/10.1016/j.scienta.2016.02.002

Cushman, J. C., \& Bohnert, H. J. (2000). Genomic approaches to plant stress tolerance. Current opinion in plant biology, 3(2), 117-124. https://doi.org/10.1016/S1369-5266(99)00052-7

Dalla Guda, C., Scordo, E., Castello, S., Paterniani, T., Palagi, M., \& Farina, E. (2002, March). Advanced Production Techniques for Limonium gmelinii. In VI International Symposium on Protected Cultivation in Mild Winter Climate: Product and Process Innovation 614 (pp. 109-113). https://doi.org/10.17660/ActaHortic.2003.614.14

Damour, G., Vandame, M., \& Urban, L. (2008). Long-term drought modifies the fundamental relationships between light exposure, leaf nitrogen content and photosynthetic capacity in leaves of the lychee tree (Litchi chinensis). Journal of plant physiology, 165(13), 1370-1378. https://doi.org/10.1016/j.jplph.2007.10.014 
Depuydt, S., \& Hardtke, C. S. (2011). Hormone signalling crosstalk in plant growth regulation. Current Biology, 21(9), R365-R373. https://doi.org/10.1016/j.cub.2011.03.013

Dhanapal, A. P., \& Crisosto, C. H. (2013). Association genetics of chilling injury susceptibility in peach (Prunus persica (L.) Batsch) across multiple years. 3 Biotech, 3(6), 481-490. https://doi.org/10.1007/s13205012-0109-x

Ding, L., Li, Y., Wang, Y., Gao, L., Wang, M., Chaumont, F., . . \& Guo, S. (2016). Root ABA accumulation enhances rice seedling drought tolerance under ammonium supply: interaction with aquaporins. Frontiers in plant science, 7, 1206. https://doi.org/10.3389/fpls.2016.01206

Ding, Y., Shi, Y., \& Yang, S. (2019). Advances and challenges in uncovering cold tolerance regulatory mechanisms in plants. New Phytologist, 222(4), 1690-1704. https://doi.org/10.1111/nph.15696

Dos Reis, S. P., Lima, A. M., \& De Souza, C. R. B. (2012). Recent molecular advances on downstream plant responses to abiotic stress. International Journal of Molecular Sciences, 13(7), 8628-8647. https://doi.org/10.3390/ijms13078628

Du, H., Wu, N., Fu, J., Wang, S., Li, X., Xiao, J., \& Xiong, L. (2012). A GH3 family member, OsGH3-2, modulates auxin and abscisic acid levels and differentially affects drought and cold tolerance in rice. Journal of experimental botany, 63(18), 6467-6480. https://doi.org/10.1093/jxb/ers300

Fahad, S., Nie, L., Chen, Y., Wu, C., Xiong, D., Saud, S., .. \& Huang, J. (2015). Crop plant hormones and environmental stress. In Sustainable Agriculture Reviews (pp. 371-400). Springer, Cham. https://doi.org/10.1007/978-3-319-09132-7_10

Farinati, F., Piciocchi, M., Lavezzo, E., Bortolami, M., \& Cardin, R. (2010). Oxidative stress and inducible nitric oxide synthase induction in carcinogenesis. Digestive Diseases, 28(4-5), 579-584. https://doi.org/10.1159/000320052

Farooq, M., Wahid, A., Kobayashi, N., Fujita, D. B. S. M. A., \& Basra, S. M. A. (2009). Plant drought stress: effects, mechanisms and management. In Sustainable agriculture (pp. 153-188). Springer, Dordrecht. DOI: https://doi.org/10.1007/978-90-481-2666-8_12

Fediuc, E., Lips, S. H., \& Erdei, L. (2005). O-acetylserine (thiol) lyase activity in Phragmites and Typha plants under cadmium and $\mathrm{NaCl}$ stress conditions and the involvement of ABA in the stress response. Journal of plant physiology, 162(8), 865-872. https://doi.org/10.1016/j.jplph.2004.11.015

Foyer, C. H., \& Noctor, G. (2000). Tansley review No. 112: oxygen processing in photosynthesis: regulation and signalling. New phytologist, 146(3), 359-388. https://doi.org/10.1046/j.1469-8137.2000.00667.x

Fozouni, M., Abbaspour, N., \& Baneh, H. D. (2012). Leaf water potential, photosynthetic pigments and compatible solutes alterations in four grape cultivars under salinity. Vitis, 51(4), 147-152.

Fu, J., Wu, H., Ma, S., Xiang, D., Liu, R., \& Xiong, L. (2017). OsJAZ1 attenuates drought resistance by regulating $\mathrm{JA}$ and $\mathrm{ABA}$ signaling in rice. Frontiers in plant science, 8, 2108. https://doi.org/10.3389/fpls.2017.02108

Fukao, T., Yeung, E., \& Bailey-Serres, J. (2011). The submergence tolerance regulator SUB1A mediates crosstalk between submergence and drought tolerance in rice. The Plant Cell, 23(1), 412-427. DOI: https://doi.org/10.1105/tpc.110.080325

Furr, J. R., \& Armstrong, W. W. (1975). Water and salinity problems of Abadan Island date gardens. Ann. Date Growers Inst, 52, 14-17.

Fusco, N., Micheletto, L., Dal Corso, G., Borgato, L., \& Furini, A. (2005). Identification of cadmiumregulated genes by cDNA-AFLP in the heavy metal accumulator Brassica juncea L. Journal of Experimental Botany, 56(421), 3017-3027. https://doi.org/10.1093/jxb/eri299 
Fusseder, A., Wartinger, A., Hartung, W., Schulze, E. D., \& Heilmeier, H. (1992). Cytokinins in the xylem sap of desert-grown almond (Prunus dulcis+) trees: Daily courses and their possible interactions with abscisic acid and leaf conductance. New Phytologist, 122(1), 45-52. https://doi.org/10.1111/j.14698137.1992.tb00051.x

Galvan-Ampudia, C. S., Julkowska, M. M., Darwish, E., Gandullo, J., Korver, R. A., Brunoud, G., ... \& Testerink, C. (2013). Halotropism is a response of plant roots to avoid a saline environment. Current Biology, 23(20), 2044-2050. https://doi.org/10.1016/j.cub.2013.08.042

Garg, R., Bhattacharjee, A., \& Jain, M. (2015). Genome-scale transcriptomic insights into molecular aspects of abiotic stress responses in chickpea. Plant Molecular Biology Reporter, 33(3), 388-400. https://doi.org/10.1007/s11105-014-0753-x

George, A. P., \& Nissen, R. J. (1992). Effects of water stress, nitrogen and paclobutrazol on flowering, yield and fruit quality of the low-chill peach cultivar,'Flordaprince'. Scientia Horticulturae, 49(3-4), 197-209. https://doi.org/10.1016/0304-4238(92)90157-8

George, R. J., Nulsen, R. A., Ferdowsian, R., Raper, G. P., \& Thorburn, P. (1999). Trees are part of the answer but they are not the solution to dryland salinity in Western Australia. Water and Salinity Issues in Agroforestry No. 4, 47.

Gibbs, D. J., Conde, J. V., Berckhan, S., Prasad, G., Mendiondo, G. M., \& Holdsworth, M. J. (2015). Group VII ethylene response factors coordinate oxygen and nitric oxide signal transduction and stress responses in plants. Plant Physiology, 169(1), 23-31. DOI: https://doi.org/10.1104/pp.15.00338

Gibbs, D. J., Lee, S. C., Isa, N. M., Gramuglia, S., Fukao, T., Bassel, G. W., .. \& Holdsworth, M. J. (2011). Homeostatic response to hypoxia is regulated by the N-end rule pathway in plants. Nature, 479(7373), 415-418. https://doi.org/10.1038/nature10534

Gimeno, V., Syvertsen, J. P., Nieves, M., Simon, I., Martinez, V., \& Garcia-Sanchez, F. (2009). Additional nitrogen fertilization affects salt tolerance of lemon trees on different rootstocks. Scientia Horticulturae, 121(3), 298-305. https://doi.org/10.1016/j.scienta.2009.02.019

Gonai, T., Kawahara, S., Tougou, M., Satoh, S., Hashiba, T., Hirai, N., .. \& \& Yoshioka, T. (2004). Abscisic acid in the thermoinhibition of lettuce seed germination and enhancement of its catabolism by gibberellin. Journal of Experimental Botany, 55(394), 111-118. https://doi.org/10.1093/jxb/erh023

Gong, F., Hu, X., \& Wang, W. (2015). Proteomic analysis of crop plants under abiotic stress conditions: where to focus our research?. Frontiers in plant science, 6, 418. https://doi.org/10.3389/fpls.2015.00418

Greenway, H., \& Munns, R. (1980). Mechanisms of salt tolerance in nonhalophytes. Annual review of plant physiology, 31(1), 149-190.

Gururani, M. A., Venkatesh, J., \& Tran, L. S. P. (2015). Regulation of photosynthesis during abiotic stressinduced photoinhibition. Molecular plant, 8(9), 1304-1320. https://doi.org/10.1016/j.molp.2015.05.005

Hannah, M. A., Heyer, A. G., \& Hincha, D. K. (2005). A global survey of gene regulation during cold acclimation in Arabidopsis thaliana. PLoS Genet, 1(2), e26. https://doi.org/10.1371/journal.pgen.0010026

Hattori, Y., Nagai, K., Furukawa, S., Song, X. J., Kawano, R., Sakakibara, H., . . \& Matsuoka, M. (2009). The ethylene response factors SNORKEL1 and SNORKEL2 allow rice to adapt to deep water. Nature, 460(7258), 1026-1030. https://doi.org/10.1038/nature08258

Herbette, S., de Labrouhe, D. T., Drevet, J. R., \& Roeckel-Drevet, P. (2011). Transgenic tomatoes showing higher glutathione peroxydase antioxidant activity are more resistant to an abiotic stress but more susceptible to biotic stresses. Plant Science, 180(3), 548-553. https://doi.org/10.1016/j.plantsci.2010.12.002

Hirano, T. (2012). Condensins: universal organizers of chromosomes with diverse functions. Genes \& development, 26(15), 1659-1678. http://www.genesdev.org/cgi/doi/10.1101/gad.194746.112. 
Houimli, S. I. M., Denden, M., \& Mouhandes, B. D. (2010). Effects of 24-epibrassinolide on growth, chlorophyll, electrolyte leakage and proline by pepper plants under NaCl-stress. EurAsian Journal of BioSciences, 4(1), 96-104. https://doi.org/10.5053/ejobios.2010.4.0.12

Hsu, Y. T., \& Kao, C. H. (2003). Role of abscisic acid in cadmium tolerance of rice (Oryza sativa L.) seedlings. Plant, cell \& environment, 26(6), 867-874. https://doi.org/10.1046/j.1365-3040.2003.01018.x

Hu, W., Hu, G., \& Han, B. (2009). Genome-wide survey and expression profiling of heat shock proteins and heat shock factors revealed overlapped and stress specific response under abiotic stresses in rice. Plant Science, 176(4), 583-590. https://doi.org/10.1016/j.plantsci.2009.01.016

Hu, Y. R., Ma, H., Zou, Z. Y., He, K., Xiao, Y. B., Wang, Y., .. \& Li, X. G. (2017). Activation of Akt and JNK/Nrf2/NQO1 pathway contributes to the protective effect of coptisine against AAPH-induced oxidative stress. Biomedicine \& Pharmacotherapy, 85, 313-322. https://doi.org/10.1016/j.biopha.2016.11.031

Hyun, Y., Richter, R., \& Coupland, G. (2017). Competence to flower: age-controlled sensitivity to environmental cues. Plant physiology, 173(1), 36-46. DOI: https://doi.org/10.1104/pp.16.01523

Iqbal, N., Umar, S., \& Khan, N. A. (2015). Nitrogen availability regulates proline and ethylene production and alleviates salinity stress in mustard (Brassica juncea). Journal of Plant Physiology, 178, 84-91. https://doi.org/10.1016/j.jplph.2015.02.006

Issarakraisila, M., Ma, Q., \& Turner, D. W. (2007). Photosynthetic and growth responses of juvenile Chinese kale (Brassica oleracea var. alboglabra) and Caisin (Brassica rapa subsp. parachinensis) to waterlogging and water deficit. Scientia horticulturae, 111(2), 107-113. https://doi.org/10.1016/j.scienta.2006.10.017

Ivanov, Y. V., Kartashov, A. V., Ivanova, A. I., Savochkin, Y. V., \& Kuznetsov, V. V. (2016). Effects of zinc on Scots pine (Pinus sylvestris L.) seedlings grown in hydroculture. Plant Physiology and Biochemistry, 102, 1-9. https://doi.org/10.1016/j.plaphy.2016.02.014

Iwamoto, M., Kiyota, S., Hanada, A., Yamaguchi, S., \& Takano, M. (2011). The multiple contributions of phytochromes to the control of internode elongation in rice. Plant physiology, 157(3), 1187-1195. DOI: https://doi.org/10.1104/pp.111.184861

Jacobsen, S. E., \& Olszewski, N. E. (1993). Mutations at the SPINDLY locus of Arabidopsis alter gibberellin signal transduction. The Plant Cell, 5(8), 887-896. DOI: https://doi.org/10.1105/tpc.5.8.887

Jain, M., \& Khurana, J. P. (2009). Transcript profiling reveals diverse roles of auxin-responsive genes during reproductive development and abiotic stress in rice. The FEBS journal, 276(11), 3148-3162. https://doi.org/10.1111/j.1742-4658.2009.07033.x

Jain, M., Ghanashyam, C., \& Bhattacharjee, A. (2010). Comprehensive expression analysis suggests overlapping and specific roles of rice glutathione S-transferase genes during development and stress responses. BMC genomics, 11(1), 73. https://doi.org/10.1186/1471-2164-11-73

Jalili, F., Khavazi, K., Pazira, E., Nejati, A., Rahmani, H. A., Sadaghiani, H. R., \& Miransari, M. (2009). Isolation and characterization of ACC deaminase-producing fluorescent pseudomonads, to alleviate salinity stress on canola (Brassica napus L.) growth. Journal of plant physiology, 166(6), 667-674. https://doi.org/10.1016/j.jplph.2008.08.004

Janeczko, A., Gullner, G., Skoczowski, A., Dubert, F., \& Barna, B. (2007). Effects of brassinosteroid infiltration prior to cold treatment on ion leakage and pigment contents in rape leaves. Biologia Plantarum, 51(2), 355-358. https://doi.org/10.1007/s10535-007-0072-2

Juszczak, I., \& Bartels, D. (2017). LEA gene expression, RNA stability and pigment accumulation in three closely related Linderniaceae species differing in desiccation tolerance. Plant Science, 255, 59-71. https://doi.org/10.1016/j.plantsci.2016.10.003 
Kang, G., Wang, C., Sun, G., \& Wang, Z. (2003). Salicylic acid changes activities of H2O2-metabolizing enzymes and increases the chilling tolerance of banana seedlings. Environmental and Experimental Botany, 50(1), 9-15. https://doi.org/10.1016/S0098-8472(02)00109-0

Kang, Y. U. N., Outlaw Jr, W. H., Andersen, P. C., \& Fiore, G. B. (2007). Guard-cell apoplastic sucrose concentration-a link between leaf photosynthesis and stomatal aperture size in the apoplastic phloem loader Vicia faba L. Plant, Cell \& Environment, 30(5), 551-558. https://doi.org/10.1111/j.1365-3040.2007.01635.x

Kim, H., Hwang, H., Hong, J. W., Lee, Y. N., Ahn, I. P., Yoon, I. S., . \& \& Kim, B. G. (2012). A rice orthologue of the ABA receptor, OsPYL/RCAR5, is a positive regulator of the ABA signal transduction pathway in seed germination and early seedling growth. Journal of experimental botany, 63(2), 1013-1024. https://doi.org/10.1093/jxb/err338

Kim, J. J., Lee, J. H., Kim, W., Jung, H. S., Huijser, P., \& Ahn, J. H. (2012). The microRNA156SQUAMOSA PROMOTER BINDING PROTEIN-LIKE3 module regulates ambient temperature-responsive flowering via FLOWERING LOCUS T in Arabidopsis. Plant Physiology, 159(1), 461-478. DOI: https://doi.org/10.1104/pp.111.192369

Kinoshita, N., Wang, H., Kasahara, H., Liu, J., MacPherson, C., Machida, Y., .. \& Chua, N. H. (2012). IAA-Ala Resistant3, an evolutionarily conserved target of miR167, mediates Arabidopsis root architecture changes during high osmotic stress. The Plant Cell, 24(9), 3590-3602. DOI: https://doi.org/10.1105/tpc.112.097006

Klingler, J. P., Batelli, G., \& Zhu, J. K. (2010). ABA receptors: the START of a new paradigm in phytohormone signalling. Journal of experimental botany, 61(12), 3199-3210. https://doi.org/10.1093/jxb/erq151

Kodur, S., Tisdall, J. M., Tang, C., \& Walker, R. R. (2010). Accumulation of potassium in grapevine rootstocks (Vitis) grafted to 'Shiraz'as affected by growth, root-traits and transpiration. Vitis, 49(1), 7-13.

Kovtun, Y., Chiu, W. L., Zeng, W., \& Sheen, J. (1998). Suppression of auxin signal transduction by a MAPK cascade in higher plants. Nature, 395(6703), 716-720. https://doi.org/10.1038/27240

Krishna, K. B., Sathasivan, A., \& Sarker, D. C. (2012). Evidence of soluble microbial products accelerating chloramine decay in nitrifying bulk water samples. Water research, 46(13), 3977-3988. https://doi.org/10.1016/j.watres.2012.05.026

Kuromori, T., Fujita, M., Urano, K., Tanabata, T., Sugimoto, E., \& Shinozaki, K. (2016). Overexpression of AtABCG25 enhances the abscisic acid signal in guard cells and improves plant water use efficiency. Plant Science, 251, 75-81. https://doi.org/10.1016/j.plantsci.2016.02.019

Larkindale, J., \& Vierling, E. (2008). Core genome responses involved in acclimation to high temperature. Plant physiology, 146(2), 748-761. DOI: https://doi.org/10.1104/pp.107.112060

Larson, K. D., Schaffer, B., \& Davies, F. S. (1991). Flooding, leaf gas exchange, and growth of mango in containers. Journal of the American Society for Horticultural Science, 116(1), 156-160. https://doi.org/10.21273/JASHS.116.1.156

Lavenus, J., Goh, T., Roberts, I., Guyomarc'h, S., Lucas, M., De Smet, I., .. \& \& Laplaze, L. (2013). Lateral root development in Arabidopsis: fifty shades of auxin. Trends in plant science, 18(8), 450-458. https://doi.org/10.1016/j.tplants.2013.04.006

Lavenus, J., Goh, T., Roberts, I., Guyomarc'h, S., Lucas, M., De Smet, I., .. \& Laplaze, L. (2013). Lateral root development in Arabidopsis: fifty shades of auxin. Trends in plant science, 18(8), 450-458. https://doi.org/10.1016/j.tplants.2013.04.006

Levitt, J. (1980). Responses of plants to environmental stresses. Water, radiation, salt, and other stresses, 2. DOI:10.1086/412488 
Lim, C. W., Baek, W., Jung, J., Kim, J. H., \& Lee, S. C. (2015). Function of ABA in stomatal defense against biotic and drought stresses. International journal of molecular sciences, 16(7), 15251-15270. https://doi.org/10.3390/ijms160715251

Liu, J. H., Kitashiba, H., Wang, J., Ban, Y., \& Moriguchi, T. (2007). Polyamines and their ability to provide environmental stress tolerance to plants. Plant Biotechnology, 24(1), 117-126. https://doi.org/10.5511/plantbiotechnology.24.117

Liu, M., Peng, Y., Wang, S., Liu, T., \& Xiao, H. (2014). Enhancement of anammox activity by addition of compatible solutes at high salinity conditions. Bioresource technology, 167, 560-563. https://doi.org/10.1016/j.biortech.2014.06.015

Llanes, A., Andrade, A., Masciarelli, O., Alemano, S., \& Luna, V. (2016). Drought and salinity alter endogenous hormonal profiles at the seed germination phase. Seed Science Research, 26(1), 1-13. https://doi.org/10.1017/S0960258515000331

Lombi, E., Zhao, F. J., Dunham, S. J., \& McGrath, S. P. (2001). Phytoremediation of heavy metalcontaminated soils: Natural hyperaccumulation versus chemically enhanced phytoextraction. Journal of Environmental Quality, 30(6), 1919-1926. https://doi.org/10.2134/jeq2001.1919

Lurie, S., \& Crisosto, C. H. (2005). Chilling injury in peach and nectarine. Postharvest biology and technology, 37(3), 195-208. https://doi.org/10.1016/j.postharvbio.2005.04.012

Maggio, A., De Pascale, S., Fagnano, M., \& Barbieri, G. (2011). Saline agriculture in Mediterranean environments. Italian journal of Agronomy, e7-e7. https://doi.org/10.4081/ija.2011.e7

Mahajan, S., \& Tuteja, N. (2005). Cold, salinity and drought stresses: an overview. Archives of biochemistry and biophysics, 444(2), 139-158. https://doi.org/10.1016/j.abb.2005.10.018

Marcelis, L. F., Heuvelink, E., \& Goudriaan, J. (1998). Modelling biomass production and yield of horticultural crops: a review. Scientia Horticulturae, 74(1-2), 83-111. https://doi.org/10.1016/S03044238(98)00083-1

Masood, A., Khan, M. I. R., Fatma, M., Asgher, M., Per, T. S., \& Khan, N. A. (2016). Involvement of ethylene in gibberellic acid-induced sulfur assimilation, photosynthetic responses, and alleviation of cadmium stress in mustard. Plant Physiology and Biochemistry, 104, 1-10. https://doi.org/10.1016/j.plaphy.2016.03.017

Medici, A., Laloi, M., \& Atanassova, R. (2014). Profiling of sugar transporter genes in grapevine coping with water deficit. FEBS letters, 588(21), 3989-3997. https://doi.org/10.1016/j.envexpbot.2013.10.019

Meena, S. K., Gupta, N. K., Gupta, S., Khandelwal, S. K., \& Sastry, E. V. D. (2003). Effect of sodium chloride on the growth and gas exchange of young Ziziphus seedling rootstocks. The Journal of Horticultural Science and Biotechnology, 78(4), 454-457. https://doi.org/10.1080/14620316.2003.11511649

Mehdi-Tounsi, H., Chelli-Chaabouni, A., Mahjoub-Boujnah, D., \& Boukhris, M. (2017). Long-term field response of pistachio to irrigation water salinity. Agricultural Water Management, 185, 1-12. https://doi.org/10.1016/j.agwat.2017.02.003

Mico, C., Recatala, L., Peris, M., \& Sanchez, J. (2006). Assessing heavy metal sources in agricultural soils of an European Mediterranean area by multivariate analysis. Chemosphere, 65(5), 863-872. https://doi.org/10.1016/j.chemosphere.2006.03.016

Mishra, S. K., Tripp, J., Winkelhaus, S., Tschiersch, B., Theres, K., Nover, L., \& Scharf, K. D. (2002). In the complex family of heat stress transcription factors, HsfA1 has a unique role as master regulator of thermotolerance in tomato. Genes \& Development, 16(12), 1555-1567. doi/10.1101/gad.228802.

Mohamed, H. I., \& Latif, H. H. (2017). Improvement of drought tolerance of soybean plants by using methyl 
jasmonate. Physiology and Molecular Biology of Plants, 23(3), 545-556. https://doi.org/10.1007/s12298017-0451-x

Mohammadkhani, S., Shahverdi, H., \& Esfahany, M. N. (2018). Impact of salinity and connate water on low salinity water injection in secondary and tertiary stages for enhanced oil recovery in carbonate oil reservoirs. Journal of Geophysics and Engineering, 15(4), 1242-1254. https://doi.org/10.1088/1742-2140/aaae84

Monni, S., Uhlig, C., Hansen, E., \& Magel, E. (2001). Ecophysiological responses of Empetrum nigrum to heavy metal pollution. Environmental Pollution, 112(2), 121-129. https://doi.org/10.1016/S02697491(00)00125-1

Munns, R. (2011). Plant adaptations to salt and water stress: differences and commonalities. In Advances in botanical research (Vol. 57, pp. 1-32). Academic Press. https://doi.org/10.1016/B978-0-12-387692-8.000011

Munns, R., \& Tester, M. (2008). Mechanisms of salinity tolerance. Annu. Rev. Plant Biol., 59, 651-681. https://doi.org/10.1146/annurev.arplant.59.032607.092911

Naeini, M. R., Khoshgoftarmanesh, A. H., \& Fallahi, E. (2006). Partitioning of chlorine, sodium, and potassium and shoot growth of three pomegranate cultivars under different levels of salinity. Journal of Plant Nutrition, 29(10), 1835-1843. https://doi.org/10.1080/01904160600899352

Navarro, A., Sanchez-Blanco, M. J., \& Banon, S. (2007). Influence of paclobutrazol on water consumption and plant performance of Arbutus unedo seedlings. Scientia Horticulturae, 111(2), 133-139. https://doi.org/10.1016/j.scienta.2006.10.014

Ng, L. M., Melcher, K., Teh, B. T., \& Xu, H. E. (2014). Abscisic acid perception and signaling: structural mechanisms and applications. Acta Pharmacologica Sinica, 35(5), 567-584. https://doi.org/10.1038/aps.2014.5

Nishiyama, R., Watanabe, Y., Leyva-Gonzalez, M. A., Van Ha, C., Fujita, Y., Tanaka, M., .. \& Tran, L. S. P. (2013). Arabidopsis AHP2, AHP3, and AHP5 histidine phosphotransfer proteins function as redundant negative regulators of drought stress response. Proceedings of the National Academy of Sciences, 110(12), 4840-4845. https://doi.org/10.1073/pnas.1302265110

Noctor, G., Lelarge-Trouverie, C., \& Mhamdi, A. (2015). The metabolomics of oxidative stress. Phytochemistry, 112, 33-53. https://doi.org/10.1016/j.phytochem.2014.09.002

Noriega, G., Caggiano, E., Lecube, M. L., Santa Cruz, D., Batlle, A., Tomaro, M., \& Balestrasse, K. B. (2012). The role of salicylic acid in the prevention of oxidative stress elicited by cadmium in soybean plants. Biometals, 25(6), 1155-1165. https://doi.org/10.1007/s10534-012-9577-z

Ogasawara, N., Hiramasu, T., Ishiyama, K., Fushimi, H., Suzuki, H., \& Takagi, H. (2001). Effects of gibberellic acid and temperature on growth and root carbohydrates of Delphinium seedlings. Plant growth regulation, 33(3), 181-187. https://doi.org/10.1023/A:1017593815746

Ogawa, T., Pan, L., Kawai-Yamada, M., Yu, L. H., Yamamura, S., Koyama, T., .. \& Uchimiya, H. (2005). Functional analysis of Arabidopsis ethylene-responsive element binding protein conferring resistance to Bax and abiotic stress-induced plant cell death. Plant physiology, 138(3), 1436-1445. DOI: https://doi.org/10.1104/pp.105.063586

Okushima, Y., Fukaki, H., Onoda, M., Theologis, A., \& Tasaka, M. (2007). ARF7 and ARF19 regulate lateral root formation via direct activation of LBD/ASL genes in Arabidopsis. The Plant Cell, 19(1), 118-130. DOI: https://doi.org/10.1105/tpc.106.047761

Pan, C., Tian, K., Ban, Q., Wang, L., Sun, Q., He, Y., .. \& \& Jiang, C. (2017). Genome-wide analysis of the biosynthesis and deactivation of gibberellin-dioxygenases gene family in Camellia sinensis (L.) O. Kuntze. Genes, 8(9), 235. https://doi.org/10.3390/genes8090235 
Pandey, P., Irulappan, V., Bagavathiannan, M. V., \& Senthil-Kumar, M. (2017). Impact of combined abiotic and biotic stresses on plant growth and avenues for crop improvement by exploiting physio-morphological traits. Frontiers in plant science, 8, 537. https://doi.org/10.3389/fpls.2017.00537

Papdi, C., Perez-Salamo, I., Joseph, M. P., Giuntoli, B., Bogre, L., Koncz, C., \& Szabados, L. (2015). The low oxygen, oxidative and osmotic stress responses synergistically act through the ethylene response factor VII genes RAP 2.12, RAP 2.2 and RAP 2.3. The Plant Journal, 82(5), 772-784. https://doi.org/10.1111/tpj.12848

Parajuli, R., Thoma, G., \& Matlock, M. D. (2019). Environmental sustainability of fruit and vegetable production supply chains in the face of climate change: A review. Science of the Total Environment, 650, 2863-2879. https://doi.org/10.1016/j.scitotenv.2018.10.019

PARK, E. J., JEKNIĆ, Z., PINO, M. T., Murata, N., \& CHEN, T. H. H. (2007). Glycinebetaine accumulation is more effective in chloroplasts than in the cytosol for protecting transgenic tomato plants against abiotic stress. Plant, Cell \& Environment, 30(8), 994-1005. https://doi.org/10.1111/j.1365-3040.2007.01694.x

Pasternak, T., Potters, G., Caubergs, R., \& Jansen, M. A. (2005). Complementary interactions between oxidative stress and auxins control plant growth responses at plant, organ, and cellular level. Journal of Experimental Botany, 56(418), 1991-2001. https://doi.org/10.1093/jxb/eri196

Patanè, C., \& Cosentino, S. L. (2013). Yield, water use and radiation use efficiencies of kenaf (Hibiscus cannabinus L.) under reduced water and nitrogen soil availability in a semi-arid Mediterranean area. European journal of agronomy, 46, 53-62. https://doi.org/10.1016/j.eja.2012.12.002

Patel, A. V., Bernstein, L., Deka, A., Feigelson, H. S., Campbell, P. T., Gapstur, S. M., ... \& Thun, M. J. (2010). Leisure time spent sitting in relation to total mortality in a prospective cohort of US adults. American journal of epidemiology, 172(4), 419-429.

Patel, N. M., Sadaria, S. G., Kaneria, B. B., \& Khanpara, V. D. (1995). Effect of nitrogen, potassium and zinc on growth and yield of wheat (Triticum aestivum). Indian Journal of Agronomy, 40(2), 290-291.

Proebsting Jr, E. L., \& Mills, H. H. (1978). A synoptic analysis of peach and cherry flower bud hardiness [Elevation, soil type, cultural practices, cold resistance]. Journal American Society for Horticultural Science.

Qin, X., \& Zeevaart, J. A. (1999). The 9-cis-epoxycarotenoid cleavage reaction is the key regulatory step of abscisic acid biosynthesis in water-stressed bean. Proceedings of the National Academy of sciences, 96(26), 15354-15361. https://doi.org/10.1073/pnas.96.26.15354

Qin, X., \& Zeevaart, J. A. (2002). Overexpression of a 9-cis-epoxycarotenoid dioxygenase gene in Nicotiana plumbaginifolia increases abscisic acid and phaseic acid levels and enhances drought tolerance. Plant physiology, 128(2), 544-551. DOI: https://doi.org/10.1104/pp.010663

Raga, V., Intrigliolo, D. S., Bernet, G. P., Carbonell, E. A., \& Asins, M. J. (2016). Genetic analysis of salt tolerance in a progeny derived from the citrus rootstocks Cleopatra mandarin and trifoliate orange. Tree Genetics \& Genomes, 12(3), 34. DOI 10.1007/s11295-016-0991-1

Ramoliya, P. J., \& Pandey, A. N. (2003). Soil salinity and water status affect growth of Phoenix dactylifera seedlings. New Zealand Journal of Crop and Horticultural Science, 31(4), 345-353. https://doi.org/10.1080/01140671.2003.9514270

Rangan, P., Subramani, R., Kumar, R., Singh, A. K., \& Singh, R. (2014). Recent advances in polyamine metabolism and abiotic stress tolerance. BioMed Research International, 2014. https://doi.org/10.1155/2014/239621

Rao, R., \& Li, Y. (2003). Management of flooding effects on growth of vegetable and selected field crops. HortTechnology, 13(4), 610-616. https://doi.org/10.21273/HORTTECH.13.4.0610 
Rauser, W. E., \& Dumbroff, E. B. (1981). Effects of excess cobalt, nickel and zinc on the water relations of Phaseolus vulgaris. Environmental and Experimental Botany, 21(2), 249-255. https://doi.org/10.1016/00988472(81)90032-0

Ristic, Z., Bukovnik, U., Prasad, P. V., \& West, M. (2008). A model for prediction of heat stability of photosynthetic membranes. Crop Science, 48(4), 1513-1522. https://doi.org/10.2135/cropsci2007.11.0648

Rodríguez, A., Rodríguez, B., Curbelo, Á. J., Pérez, A., Marrero, S., \& Negro, J. J. (2012). Factors affecting mortality of shearwaters stranded by light pollution. Animal Conservation, 15(5), 519-526. https://doi.org/10.1111/j.1469-1795.2012.00544.x

Romero-Aranda, R., Moya, J. L., Tadeo, F. R., Legaz, F., Primo-Millo, E., \& Talon, M. (1998). Physiological and anatomical disturbances induced by chloride salts in sensitive and tolerant citrus: beneficial and detrimental effects of cations. Plant, Cell \& Environment, 21(12), 1243-1253. https://doi.org/10.1046/j.13653040.1998.00349.x

Roy, B., Sengupta, D., \& Basu, B. (2014). Graphene oxide (GO)-catalyzed chemoselective thioacetalization of aldehydes under solvent-free conditions. Tetrahedron Letters, 55(48), 6596-6600. https://doi.org/10.1016/j.tetlet.2014.10.043

Roy, M., \& McDonald, L. M. (2015). Metal uptake in plants and health risk assessments in metal-contaminated smelter soils. Land Degradation \& Development, 26(8), 785-792. https://doi.org/10.1002/ldr.2237

RRoychoudhury, A., Paul, S., \& Basu, S. (2013). Cross-talk between abscisic acid-dependent and abscisic acid-independent pathways during abiotic stress. Plant Cell Reports, 32(7), 985-1006. https://doi.org/10.1007/s00299-013-1414-5

Rui, M., Ma, C., Hao, Y., Guo, J., Rui, Y., Tang, X., .. \& \& Zhu, S. (2016). Iron oxide nanoparticles as a potential iron fertilizer for peanut (Arachis hypogaea). Frontiers in plant science, 7, 815. https://doi.org/10.3389/fpls.2016.00815

Saidi, Y., Finka, A., \& Goloubinoff, P. (2011). Heat perception and signalling in plants: a tortuous path to thermotolerance. New Phytologist, 190(3), 556-565. https://doi.org/10.1111/j.1469-8137.2010.03571.x

Satisha, J., Prakash, G. S., Murti, G. S. R., \& Upreti, K. K. (2005). Response of grape genotypes to water deficit: Root, shoot, growth and endogenous hormones. Indian journal of plant physiology, 10(3), 225.

Savchenko, T., Kolla, V. A., Wang, C. Q., Nasafi, Z., Hicks, D. R., Phadungchob, B., .. \& Dehesh, K. (2014). Functional convergence of oxylipin and abscisic acid pathways controls stomatal closure in response to drought. Plant Physiology, 164(3), 1151-1160. DOI: https://doi.org/10.1104/pp.113.234310

Schaffer, B., Andersen, P. C., \& Ploetz, R. C. (1992). Responses of fruit crops to flooding. Horticultural reviews, 13, 257-313.

Schmutz, U., \& Ludders, P. (1999). Effect of $\mathrm{NaCl}$ salinity on growth, leaf gas exchange, and mineral composition of grafted mango rootstocks. Gartenbauwissenschaft (Germany).

Sengupta, S., Patra, B., Ray, S., \& Majumder, A. L. (2008). Inositol methyl tranferase from a halophytic wild rice, Porteresia coarctata Roxb.(Tateoka): regulation of pinitol synthesis under abiotic stress. Plant, Cell \& Environment, 31(10), 1442-1459. https://doi.org/10.1111/j.1365-3040.2008.01850.x

Seo, J. S., Joo, J., Kim, M. J., Kim, Y. K., Nahm, B. H., Song, S. I., . \& \& Choi, Y. D. (2011). OsbHLH148, a basic helix-loop-helix protein, interacts with OsJAZ proteins in a jasmonate signaling pathway leading to drought tolerance in rice. The Plant Journal, 65(6), 907-921. https://doi.org/10.1111/j.1365313X.2010.04477.x

Serra, I., Strever, A., Myburgh, P. A., \& Deloire, A. (2014). the interaction between rootstocks and cultivars ( $\mathrm{V}$ itis vinifera L.) to enhance drought tolerance in grapevine. Australian Journal of Grape and Wine 
Research, 20(1), 1-14. https://doi.org/10.1111/ajgw.12054

Shannon, M. C., \& Grieve, C. M. (1998). Tolerance of vegetable crops to salinity. Scientia horticulturae, 78(1-4), 5-38. https://doi.org/10.1016/S0304-4238(98)00189-7

Shen, C., Bai, Y., Wang, S., Zhang, S., Wu, Y., Chen, M., .. \& \& Qi, Y. (2010). Expression profile of PIN, AUX/LAX and PGP auxin transporter gene families in Sorghum bicolor under phytohormone and abiotic stress. The FEBS journal, 277(14), 2954-2969. https://doi.org/10.1111/j.1742-4658.2010.07706.x

Shibasaki, K., Uemura, M., Tsurumi, S., \& Rahman, A. (2009). Auxin response in Arabidopsis under cold stress: underlying molecular mechanisms. The Plant Cell, 21(12), 3823-3838. https://doi.org/10.1105/tpc.109.069906

Shkolnik-Inbar, D., \& Bar-Zvi, D. (2010). ABI4 mediates abscisic acid and cytokinin inhibition of lateral root formation by reducing polar auxin transport in Arabidopsis. The Plant Cell, 22(11), 3560-3573. DOI: https://doi.org/10.1105/tpc.110.074641

Sirhindi, G., Mir, M. A., Sharma, P., Gill, S. S., Kaur, H., \& Mushtaq, R. (2015). Modulatory role of jasmonic acid on photosynthetic pigments, antioxidants and stress markers of Glycine max L. under nickel stress. Physiology and Molecular Biology of Plants, 21(4), 559-565. https://doi.org/10.1007/s12298-0150320-4

Skinner, J. S., von Zitzewitz, J., Szűcs, P., Marquez-Cedillo, L., Filichkin, T., Amundsen, K., ... \& Hayes, P. M. (2005). Structural, functional, and phylogenetic characterization of a large CBF gene family in barley. Plant molecular biology, 59(4), 533-551. DOI 10.1007/s11103-005-2498-2

Song, Z., Yang, G., Guo, Y., \& Zhang, T. (2012). Comparison of two chemical pretreatments of rice straw for biogas production by anaerobic digestion. BioResources, 7(3), 3223-3236.

Spoel, S. H., Koornneef, A., Claessens, S. M., Korzelius, J. P., Van Pelt, J. A., Mueller, M. J., ... \& Van Loon, L. C. (2003). NPR1 modulates cross-talk between salicylate-and jasmonate-dependent defense pathways through a novel function in the cytosol. The Plant Cell, 15(3), 760-770. DOI: https://doi.org/10.1105/tpc.009159

Starck, Z., \& Kozińska, M. (1980). Effect of phytohormones on absorption and distribution of ions in salt-stressed bean plants. Acta Societatis Botanicorum Poloniae, 49(1-2), 111-125. https://doi.org/10.5586/asbp.1980.010

Stern, R. A., Naor, A., Bar, N., Gazit, S., \& Bravdo, B. A. (2003). Xylem-sap zeatin-riboside and dihydrozeatin-riboside levels in relation to plant and soil water status and flowering in 'Mauritius' lychee. Scientia horticulturae, 98(3), 285-291. https://doi.org/10.1016/S0304-4238(02)00229-7

Stoll, M., Loveys, B., \& Dry, P. (2000). Hormonal changes induced by partial rootzone drying of irrigated grapevine. Journal of experimental botany, 51(350), 1627-1634. https://doi.org/10.1093/jexbot/51.350.1627

Sun, F., Zhang, W., Hu, H., Li, B., Wang, Y., Zhao, Y., .. \& \& Li, X. (2008). Salt modulates gravity signaling pathway to regulate growth direction of primary roots in Arabidopsis. Plant physiology, 146(1), 178-188. https://doi.org/10.1104/pp.107.109413

Swietlik, D., \& Miller, S. S. (1983). The effect of paclobutrazol on growth and response to water stress of apple seedlings. Journal of the American Society for Horticultural Science, 108(6), 1076-1080.

Tabatabaei, S. J. (2006). Effects of salinity and N on the growth, photosynthesis and N status of olive (Olea europaea L.) trees. Scientia horticulturae, 108(4), 432-438. doi: 10.1016/j.scienta.2006.02.016

Tang, Xun, et al. "Selection and validation of reference genes for RT-qPCR analysis in potato under abiotic stress." Plant Methods 13.1 (2017): 1-8. doi: 10.1186/s13007-017-0238-7 
Thompson, A. J., Mulholland, B. J., Jackson, A. C., McKee, J. M., Hilton, H. W., Symonds, R. C., ... \& Taylor, I. B. (2007). Regulation and manipulation of ABA biosynthesis in roots. Plant, cell \& environment, 30(1), 67-78. doi: 10.1111/j.1365-3040.2006.01606.x

Tran, L. S., Urao, T., Qin, F., Maruyama, K., \& Kakimoto, T. (2007). Yamaguchi-Shinozaki K. Functional analysis of AHK1/ATHK1 and cytokinin receptor histidine kinases in response to abscisic acid, drought, and salt stress in Arabidopsis. Proc Natl Acad Sci USA, 104(51), 20623-20628. doi: 10.1073/pnas.0706547105

Tuberosa, R., \& Salvi, S. (2006). Genomics-based approaches to improve drought tolerance of crops. Trends in plant science, 11(8), 405-412. doi: 10.1016/j.tplants.2006.06.003

Upreti, K. K., \& Murti, G. S. R. (2010). Response of grape rootstocks to salinity: changes in root growth, polyamines and abscisic acid. Biologia Plantarum, 54(4), 730-734. doi: 10.1007/s10535-010-0130-z

van Berkel, K., de Boer, R. J., Scheres, B., \& ten Tusscher, K. (2013). Polar auxin transport: models and mechanisms. Development, 140(11), 2253-2268. doi: 10.1242/dev.079111

Vardhini, B. V., \& Rao, S. S. R. (2003). Amelioration of osmotic stress by brassinosteroids on seed germination and seedling growth of three varieties of sorghum. Plant Growth Regulation, 41(1), 25-31. doi: 10.1023/A:1027303518467

Vaughan, M. M., Christensen, S., Schmelz, E. A., Huffaker, A., Mcauslane, H. J., Alborn, H. T., .. \& \& Teal, P. E. (2015). Accumulation of terpenoid phytoalexins in maize roots is associated with drought tolerance. Plant, cell \& environment, 38(11), 2195-2207. doi: 10.1111/pce.12482

Verma, V., Ravindran, P., \& Kumar, P. P. (2016). Plant hormone-mediated regulation of stress responses. BMC plant biology, 16(1), 86. doi: 10.1186/s12870-016-0771-y

Vernay, P., Gauthier-Moussard, C., \& Hitmi, A. (2007). Interaction of bioaccumulation of heavy metal chromium with water relation, mineral nutrition and photosynthesis in developed leaves of Lolium perenne L. Chemosphere, 68(8), 1563-1575. doi: 10.1016/j.chemosphere.2007.02.052

Wang, D., Pajerowska-Mukhtar, K., Culler, A. H., \& Dong, X. (2007). Salicylic acid inhibits pathogen growth in plants through repression of the auxin signaling pathway. Current Biology, 17(20), 1784-1790. doi: $10.1016 /$ j.cub.2007.09.025

Wang, L. J., \& Li, S. H. (2006). Salicylic acid-induced heat or cold tolerance in relation to Ca2+ homeostasis and antioxidant systems in young grape plants. Plant Science, 170(4), 685-694. doi: 10.1016/j.plantsci.2005.09.005

Wang, X., Yuan, B., Chen, Y., Li, X., \& Ren, Y. (2014). Integration of micro-filtration into osmotic membrane bioreactors to prevent salinity build-up. Bioresource technology, 167, 116-123. doi: 10.1016/j.biortech.2014.05.121

Wang, Y., Reiter, R. J., \& Chan, Z. (2018). Phytomelatonin: a universal abiotic stress regulator. Journal of Experimental Botany, 69(5), 963-974. doi: 10.1093/jxb/erx473

Wani, S. H., Kumar, V., Shriram, V., \& Sah, S. K. (2016). Phytohormones and their metabolic engineering for abiotic stress tolerance in crop plants. The Crop Journal, 4(3), 162-176. doi: 10.1016/j.cj.2016.01.010

Wasternack, C. (2014). Action of jasmonates in plant stress responses and development - applied aspects. Biotechnology advances, 32(1), 31-39. doi: 10.1016/j.biotechadv.2013.09.009

Watkinson, J. I., Sioson, A. A., Vasquez-Robinet, C., Shukla, M., Kumar, D., Ellis, M., .. \& van Zyl, L. (2003). Photosynthetic acclimation is reflected in specific patterns of gene expression in drought-stressed loblolly pine. Plant Physiology, 133(4), 1702-1716. doi: 10.1104/pp.103.026914

Weisany, W., Sohrabi, Y., Heidari, G., Siosemardeh, A., \& Badakhshan, H. (2014). Effects of zinc application on growth, absorption and distribution of mineral nutrients under salinity stress in soybean (Glycine max 
L.). Journal of plant nutrition, 37(14), 2255-2269. doi: 10.1080\%2F01904167.2014.920386

Wen, F. P., Zhang, Z. H., Bai, T., Xu, Q., \& Pan, Y. H. (2010). Proteomics reveals the effects of gibberellic acid (GA3) on salt-stressed rice (Oryza sativa L.) shoots. Plant Science, 178(2), 170-175. doi: 10.1016/j.plantsci.2009.11.006

Wien, H. C. (1997). The physiology of vegetable crops. Cab International.

Wohlbach, D. J., Quirino, B. F., \& Sussman, M. R. (2008). Analysis of the Arabidopsis histidine kinase ATHK1 reveals a connection between vegetative osmotic stress sensing and seed maturation. The Plant Cell, 20(4), 1101-1117. doi: 10.1105/tpc.107.055871

Wolters, H., \& Jürgens, G. (2009). Survival of the flexible: hormonal growth control and adaptation in plant development. Nature Reviews Genetics, 10(5), 305-317. doi: 10.1038/nrg2558

Wolters, H., \& Jürgens, G. (2009). Survival of the flexible: hormonal growth control and adaptation in plant development. Nature Reviews Genetics, 10(5), 305-317. doi: 10.1038/nrg2558

Xi, Y., Liu, J., Dong, C., \& Cheng, Z. M. M. (2017). The CBL and CIPK gene family in grapevine (Vitis vinifera ): genome-wide analysis and expression profiles in response to various abiotic stresses. Frontiers in Plant Science, 8, 978. doi: 10.3389/fpls.2017.00978

Xie, J. H., Zapata-Arias, F. J., Shen, M., \& Afza, R. (2000). Salinity tolerant performance and genetic diversity of four rice varieties. Euphytica, 116(2), 105-110. doi: 10.1023/A:1004041900101

Xiong, L., \& Zhu, J. K. (2003). Regulation of abscisic acid biosynthesis. Plant physiology, 133(1), 29-36. doi: $10.1104 /$ pp.103.025395

Xiong, L., Ishitani, M., Lee, H., \& Zhu, J. K. (2001). The Arabidopsis LOS5/ABA3 locus encodes a molybdenum cofactor sulfurase and modulates cold stress-and osmotic stress-responsive gene expression. The Plant Cell, 13(9), 2063-2083. doi: 10.1105/TPC.010101

Xiong, Q., Ma, B., Lu, X., Huang, Y. H., He, S. J., Yang, C., .. \& Wang, W. S. (2017). Ethylene-inhibited jasmonic acid biosynthesis promotes mesocotyl/coleoptile elongation of etiolated rice seedlings. The Plant Cell, 29(5), 1053-1072. doi: 10.1105/tpc.16.00981

Xu, K., Xu, X., Fukao, T., Canlas, P., Maghirang-Rodriguez, R., Heuer, S., .. \& \& Mackill, D. J. (2006). Sub1A is an ethylene-response-factor-like gene that confers submergence tolerance to rice. Nature, 442(7103), 705-708. doi: 10.1038/nature04920

Xu, W., Jia, L., Shi, W., Liang, J., Zhou, F., Li, Q., \& Zhang, J. (2013). Abscisic acid accumulation modulates auxin transport in the root tip to enhance proton secretion for maintaining root growth under moderate water stress. New Phytologist, 197(1), 139-150. doi: 10.1111/nph.12004

Xu, Y. G., Liu, R., Sui, N., Shi, W., Wang, L., Tian, C., \& Song, J. (2016). Changes in endogenous hormones and seed-coat phenolics during seed storage of two Suaeda salsa populations. Australian Journal of Botany, 64(4), 325-332. doi: 10.1071/BT16014

Yadav, S., Irfan, M., Ahmad, A., \& Hayat, S. (2011). Causes of salinity and plant manifestations to salt stress: a review. Journal of Environmental Biology, 32(5), 667.

Yang, J., Duan, G., Li, C., Liu, L., Han, G., Zhang, Y., \& Wang, C. (2019). The crosstalks between jasmonic acid and other plant hormone signaling highlight the involvement of jasmonic acid as a core component in plant response to biotic and abiotic stresses. Frontiers in plant science, 10. doi: 10.3389\%2Ffpls.2019.01349

Yang, W., Liu, X. D., Chi, X. J., Wu, C. A., Li, Y. Z., Song, L. L., .. \& Liu, Y. (2011). Dwarf apple MbDREB1 enhances plant tolerance to low temperature, drought, and salt stress via both ABA-dependent and ABA-independent pathways. Planta, 233(2), 219-229. doi: 10.1007/s00425-010-1279-6 
Yang, X., Song, J., Campbell-Palmer, L., Fillmore, S., \& Zhang, Z. (2013). Effect of ethylene and 1-MCP on expression of genes involved in ethylene biosynthesis and perception during ripening of apple fruit. Postharvest Biology and Technology, 78, 55-66. doi: 10.1016/j.postharvbio.2012.11.012

Yao, X., Xiong, W., Ye, T., \& Wu, Y. (2012). Overexpression of the aspartic protease ASPG1 gene confers drought avoidance in Arabidopsis. Journal of experimental botany, 63(7), 2579-2593. doi: 10.1093/jxb/err433

Yoshida, T., Fujita, Y., Sayama, H., Kidokoro, S., Maruyama, K., Mizoi, J., ... \& Yamaguchi-Shinozaki, K. (2010). AREB1, AREB2, and ABF3 are master transcription factors that cooperatively regulate ABREdependent ABA signaling involved in drought stress tolerance and require ABA for full activation. The Plant Journal, 61(4), 672-685. doi: 10.1111/j.1365-313X.2009.04092.x

Yun-xia, G., Li-jun, Z., Feng-hai, L., Zhi-bin, C., Che, W., Yun-cong, Y., .. \& \& Zhen-sheng, S. (2010). Relationship between jasmonic acid accumulation and senescence in drought-stress. African Journal of Agricultural Research, 5(15), 1978-1983. doi: 10.5897/AJAR.9000585

Zaid, A., \& de Wet, P. F. (2002). Date palm cultivation. Abdelouahhab Zaid (ed.) Chapter II. FAO Plant production and protection.

Zarei, M., Azizi, M., Rahemi, M., \& Tehranifar, A. (2016). Evaluation of $\mathrm{NaCl}$ salinity tolerance of four fig genotypes based on vegetative growth and ion content in leaves, shoots, and roots. HortScience, 51(11), 1427-1434. doi: 10.21273/HORTSCI11009-16

Zhang, X., Fowler, S. G., Cheng, H., Lou, Y., Rhee, S. Y., Stockinger, E. J., \& Thomashow, M. F. (2004). Freezing-sensitive tomato has a functional CBF cold response pathway, but a CBF regulon that differs from that of freezing-tolerant Arabidopsis. The Plant Journal, 39(6), 905-919. doi: 10.1111/j.1365313X.2004.02176.x

Zhao, F. Q., Zhang, Z. W., Qu, J. P., Yao, H. D., Li, M., Li, S., \& Xu, S. W. (2014). Cold stress induces antioxidants and Hsps in chicken immune organs. Cell Stress and Chaperones, 19(5), 635-648. doi: 10.1007/s12192-013-0489-9

Zhao, L., Liu, F., Xu, W., Di, C., Zhou, S., Xue, Y., .. \& \& Su, Z. (2009). Increased expression of OsSPX1 enhances cold/subfreezing tolerance in tobacco and Arabidopsis thaliana. Plant biotechnology journal, 7(6), 550-561. doi: 10.1111/j.1467-7652.2009.00423.x

Zhao, L., Liu, F., Xu, W., Di, C., Zhou, S., Xue, Y., .. \& \& Su, Z. (2009). Increased expression of OsSPX1 enhances cold/subfreezing tolerance in tobacco and Arabidopsis thaliana. Plant biotechnology journal, 7(6), 550-561. doi: 10.1111/j.1467-7652.2009.00423.x

Zhao, L., Qiu, G., Anderson, C. W., Meng, B., Wang, D., Shang, L., .. \& Feng, X. (2016). Mercury methylation in rice paddies and its possible controlling factors in the $\mathrm{Hg}$ mining area, Guizhou province, Southwest China. Environmental Pollution, 215, 1-9. doi: 10.1016/j.jag.2016.08.007

ZHAO, M. L., WANG, J. N., Shan, W., FAN, J. G., KUANG, J. F., WU, K. Q., .. \& LU, W. J. (2013). Induction of jasmonate signalling regulators MaMYC2s and their physical interactions with MaICE1 in methyl jasmonate-induced chilling tolerance in banana fruit. Plant, cell \& environment, 36(1), 30-51. doi: 10.1111/j.1365-3040.2012.02551.x

Zhao, M., Zhang, N., Gao, T., Jin, J., Jing, T., Wang, J., .. \& \& Song, C. (2020). Sesquiterpene glucosylation mediated by glucosyltransferase UGT91Q2 is involved in the modulation of cold stress tolerance in tea plants. New Phytologist, 226(2), 362-372. doi: 10.1111/nph.16364

Zhao, Y., Wang, H. P., Han, B., \& Yu, X. (2019). Coupling of abiotic stresses and phytohormones for the production of lipids and high-value by-products by microalgae: a review. Bioresource technology, 274, 549-556. doi: 10.1016/j.biortech.2018.12.030 
Zhao, Y., Wang, T., Zhang, W., \& Li, X. (2011). SOS3 mediates lateral root development under low salt stress through regulation of auxin redistribution and maxima in Arabidopsis. New Phytologist, 189(4), 1122-1134. doi: 10.1111/j.1469-8137.2010.03545.x

Zhong, R., Wang, Y., Gai, R., Xi, D., Mao, C., \& Ming, F. (2020). Rice SnRK protein kinase OsSAPK8 acts as a positive regulator in abiotic stress responses. Plant Science, 292, 110373 . doi: /10.1016/j.plantsci.2019.110373

Zhou, R., Cutler, A. J., Ambrose, S. J., Galka, M. M., Nelson, K. M., Squires, T. M., ... \& Abrams, S. R. (2004). A new abscisic acid catabolic pathway. Plant physiology, 134(1), 361-369. doi: org/10.1104/pp.103.030734

Zhu, Z., An, F., Feng, Y., Li, P., Xue, L., Mu, A., . . \& Zhang, X. (2011). Derepression of ethylene-stabilized transcription factors (EIN3/EIL1) mediates jasmonate and ethylene signaling synergy in Arabidopsis. Proceedings of the National Academy of Sciences, 108(30), 12539-12544. doi: org/10.1073/pnas.1103959108

Zolla, G., Heimer, Y. M., \& Barak, S. (2010). Mild salinity stimulates a stress-induced morphogenic response in Arabidopsis thaliana roots. Journal of experimental botany, 61(1), 211-224. doi: org/10.1093/jxb/erp290 